\title{
Effects of the European Monetary Union on High-Technology Exports
}

\author{
Timo Tohmo $^{1}$ (D) $\cdot$ Kari Heimonen ${ }^{1} \cdot$ Mika Nieminen $^{1}$
}

Received: 12 November 2019 / Revised: 28 September 2020

Accepted: 27 January 2021

Published online: 18 March 2021

(C) The Author(s) 2021

\begin{abstract}
Our study estimates the effects of the European Monetary Union (EMU) on hightechnology (HT) export and assesses the potential knowledge spillovers of such trade. Irrespective of the importance of the HT trade channel, none of the previous studies in the literature focus on the effects of a common currency on HT trade. Increasing trade in the HT sector may lead to more efficient use of resources and help countries to move towards a knowledge-based economy. Moreover, it may lead to higher overall growth. After considering multilateral resistances, pair fixed effects and bias correction in the preferred (three-way bias-corrected) model, EMU membership becomes negative and statistically non-significant for HT exports. Furthermore, our findings indicate that the effect of the EMU on HT exports is country-specific, which lends support to the notion of nonhomogenous knowledge transfer and country-related knowledge-based economic development within the EMU.
\end{abstract}

Keywords Trade $\cdot$ Exports $\cdot$ European Monetary Union $\cdot$ High technology $\cdot$ Knowledge-based economy $\cdot$ Poisson Pseudo-maximum Likelihood

\section{Introduction}

The impact of the common currency on trade has generated an extensive amount of research since the seminal paper of Rose (2000). Irrespective of this interest, some important topics

Timo Tohmo

timo.tohmo@jyu.fi

Kari Heimonen

kari.heimonen@jyu.fi

Mika Nieminen

mika.p.nieminen@jyu.fi

1 Jyväskylä University School of Business and Economics, Jyväskylä, Finland 
remain unanswered. The impact of the common currency on sectoral trade, especially on trade in the high-technology (HT) sector, is unknown despite the vital role of this sector in the economic performance of the EU. This study endeavours to fill this gap by estimating the impact of the Euro on HT trade between EU member countries.

HT trade is related to the policy goals of the EU. The development of a knowledgebased economy and new technologies has assumed the utmost importance, especially in Europe, as stated in the Lisbon Strategy (Audretsch et al. 2009). One goal of the Lisbon Agenda was to transform the EU into the world's most competitive and most dynamic knowledge-based economy by 2010. Moreover, Dohse and Soltwedel (2006) argue that by adopting the European policy strategy of producing a competitive knowledge economy, most European countries have focused on research and development (R\&D). Thus, the evolution of the HT sector is of essence for the future of the EU and is a core part of the EU strategy. One of the major welfare implications behind the common currency, the Euro, was the boost in trade, which would result in output growth. Typically, previous studies estimated only the impacts of the EMU on total trade. However, since the HT sector plays a special role in boosting productivity and increasing welfare and lies the heart of the EU policy itself, it is important to examine how the common currency has affected HT trade specifically. We expect that this trade could play an important role in technology transfer between member nations and boost their outputs. Moreover, asymmetries in HT trade can provide information about the sectoral convergence/ divergence among member countries, which is highly relevant for the success of the Euro, and by extension, the common monetary policy.

\section{Motivation of the Study: Relation of HT Trade to the EMU}

Godin (2004) state that the concept of "high tech" has become popular in member countries of the Organisation for Economic Co-operation and Development (OECD), as OECD itself actively promotes high technology as the new foundation of competitiveness and a symbol of an advanced knowledge-based economy. Moreover, the HT sector is closely related to the complexities of the economy and production (see Hausman et al. 2013). The economic complexity of a nation comprises many traditional determinants of economic growth, such as education and R\&D. Grossman and Helpman (1991), Romer (1992), and Barro and Sala-iMartin (1995) propose that countries that are more open to the rest of the world have a greater ability to absorb the technological advantages generated in leading nations. This suggests that the more open the economy of a nation, the higher its factor productivity. Trade in terms of HT goods may thus provide an extra boost for national welfare. In this study, we explicitly estimate the effects of the common currency, namely the EMU, on HT trade between the EU member countries.

The effects of the EMU on aggregate trade have been researched ever since the launch of the common currency (for a survey, see, e.g., Baldwin 2006). An increase in trade due to the adoption of a common currency further increases welfare (Frankel and Rose 2002). We contribute to this relatively large body of the literature by providing new insights. We use ex-post data and provide the very first estimates of the effects of the EMU on HT trade in particular. We also try to reveal the possible asymmetries in the reactions of the countries involved in HT trade in the EMU. In this study, we explicitly examine how the adoption of the common currency affected the exports of the HT sectors between EU member 
countries. ${ }^{1}$ In previous works, the HT sectors are aggregated with the entire trade volumes between countries; thus, HT trade has not been examined in previous studies that assessed the impacts of Preferential Trade Agreements (PTAs) or the common currency on trade. This is a serious shortcoming, since HT sectors play a potentially important role in the growth of nations, given that an overall increase in trade boosts growth.

Krugman (1979) points out how trade allows technology to become available to the less high tech countries as well, thus increasing global productivity. It is expected that the competitiveness of a given HT sector will become evident according to the amount of trade with it. Both innovations in a high-tech country and technology transfer via trade increase global output. Thus, technology and knowledge are acquired through more frequent trade, and an examination of the trade effects of the EMU on HT trade within the EU would provide valuable insights.

Moreover, valid empirical evidence shows that the technology gap between trading partners may not be too wide. Filippini and Molini (2003) provide evidence from Asia, showing that the HT gap may also decrease the amount of trade. If both trade partners have similar technological capabilities, a high volume of intra-industry trade is expected. This similarity hypothesis is consistent with predictions by both the neoclassical and new trade theories. In effect, they propose that technological level would impact the size of HT exports. If the trade partners shared a similar enough technological level, the extraction of trade barriers would enlarge the HT trade. On the other hand, if the technological levels of the trade partners are very dissimilar, it is likely that the increase in trade will occur for more traditional goods. The increases in productivity and output are smaller in the latter case. In this study, we also provide country-level estimates of the impacts of the EMU on HT trade.

A large number of studies have examined the impacts of PTAs on global trade (see, e.g., Frankel 1997). As per the overall inference concerning PTAs for Europe, the trade flows are mostly explained by the EU members' sizes, development levels, proximities as well as sharing a common language and borders. Frankel and Wei (1993) report that the stabilisation of bilateral exchange rates in the 1980s under the exchange rate mechanism of the European monetary system might be partly responsible for the increase in intra-European trade. The EC effect became statistically significant from 1985 onwards. Estimates suggest that intra EC trade exerts an effect of approximately 65\%, with the memberships in 1973 and 1983 each boosting trade by half that amount (Frankel 1997).

Frankel (1997) also stresses the significance of disaggregated data. Trade in manufactured goods and agriculture was significantly boosted within the EU countries due to trade agreements. The Treaty on European Union, which was signed in Maastricht in 1992, led to the establishment of the EU. It initiated a common market for the whole EU area, wherein not only trade and services, but also labour and capital were free to move without barriers. All these agreements had significant impacts on trade and

\footnotetext{
${ }^{1}$ The control group consists of EU members. Its purpose is to control the effects of membership to the EMU (and ensure EU policy harmonisation in general (see, e.g., Baldwin 2006; Flam 2009). Thus, we do not examine trade creation or diversion with respect to countries outside the EU zone. This could be of importance, as Carrere (2006) found that most trade agreements resulted in an increase in intra-regional trade beyond the levels predicted in the gravity models which were often coupled with a reduction in import and export from the rest of the world, suggesting evidence of trade diversion. Trade diversion is highly likely; for example, in 2019, HT products represented $19 \%$ of the total extra EU imports and $18 \%$ of the total extra EU exports. China ranked first for HT imports to the EU, ahead of the US and the UK. The US ranked first in terms of EU exports of HT products, followed by China and the UK (Eurostat, April 2020).
} 
welfare. Cecchini (1988) and Baldwin (1989) estimate that by the end of the century, the gross national product of the EU increased by $2.5-6.5 \%$ as the result of the creation of the single market in 1992. Notably, the establishment of the single market has helped increase market efficiency as well as capital and labour market flows. Increasing economic integration finally led to the establishment of an economic and monetary union. The third stage of the EMU was launched on 1 January 1999. Its creation was the final stage of the EU integration process. Berger and Nitsch (2008) propose that the EMU can be regarded as a continuum or culmination of the economic integration preceding the introduction of the Euro. The European Commission (1990) reports the potential benefits and costs of forming an economic and monetary union. Two of the major expected gains of the monetary union were the elimination of both transaction costs connected to exchange rates and the uncertainties caused by exchange rate fluctuations. Flam (2009) state that the elimination of currency transaction costs and the uncertainty connected to exchange rates produce an effect similar to that caused by a productivity increase in firms, thus stimulating trade (as a common currency affects the intensive as well as extensive margins of trade). These direct gains increase capital stock, which also leads to dynamic indirect gains. To summarize, the benefits are expected to outweigh the disadvantages. However, no attempts have been made to estimate the effects of the EMU on trade in HT sectors which, as per growth theories, could be of particular economic importance.

The European Free Trade Association (EFTA), creation of the EU and the PTAs that followed aimed to boost trade between member countries. Our study focuses only on the effects of this final step of the integration process, namely the EMU membership, on trade. There are several reasons for this choice. First, the benefits of EMU membership have been a topic of active research during the last two decades, but all the studies have ignored the potentially significant role of HT trade. That is, we lack information about the effects of the EMU on trade in the HT sector. It is also interesting to assess to what extent trade in the HT sector explains EMU membership. In effect, using dummies on the right-hand side of the gravity equations and assuming them as exogenous might be misleading and bias the results, since memberships are not random variables but are likely to reflect endogeneity in trade agreements for reasons not observable but correlated with the level of trade. This might bias the results. Magee (2003) points out that countries are likely to be preferential trade partners if they undertake significant bilateral trade, are similar in size and are both democracies. Baier and Begstrand (2004) lend support to this notion by providing empirical evidence that the variables of typical gravity equation explain the likelihood of having a free trade agreement (FTAs). Moreover, Egger et al. (2011) note that ignoring the problem of endogeneity leads to biased estimates of the impacts of PTAs on trade. Joining the EMU is a long process of convergence which lasts for several years (as defined in the Maastricht Treaty). Among others, pre-membership countries must adhere to specific currency-related mandates as per the European Exchange Rate Mechanism (ERM) target zone. In effect, joining the EMU could have already exerted some effects caused by the lower exchange rate volatility and expectations of the EMU membership.

To sum up, in this study, we answer two main research questions:

- What are the overall effects of the EMU on HT exports?

- Are the effects of the EMU on HT exports alike across different countries? 
We approach these questions by applying the traditional gravity model. Gravity models have been widely used to infer the effects of custom unions, exchange rate mechanisms, ethnic ties, linguistic identities and international borders on trade flows (Anderson and van Wincoop 2003). Empirical evidence from the ex ante evaluation of the effects of the EMU lend support to the positive impact of the common currency on trade between countries sharing this currency $^{2}$. However, the early empirical applications of the gravity equation have also encouraged criticism ${ }^{3}$, typically regarding the estimation strategies and methods that produce excessive estimates of the degree to which trade might increase.

We contribute to the literature in multiple aspects. We focus on the impacts of the common currency on HT exports. Thus, this paper provides a new and topical viewpoint for the trade literature by examining the possible channel of the growth effects of trade, particularly HT trade. We also use novel bias correction on two- and three-way PPML estimations. Our study disentangles the heterogeneous effects of the Euro on HT trade between the Euro area member countries. Our results indicate that the impact of the EMU on HT exports is close to zero, which is in line with the novel trade studies (see, e.g., Santos Silva and Tenreyro 2010; Camarero et al. 2014; Berger and Nitsch 2008). Our study also reveals some new insights; the EMU increases exports in HT sectors, but not unanimously across all member economies, indicating that knowledge spillover and diffusion via trade might not be evenly dispersed among the member states.

Our findings lend support to the notion that EMU membership has significantly expanded HT exports between some member countries. We interpret this finding as the execution of the Lisbon Strategy creating a competitive and dynamic knowledge-based economy in the EU. However, the finding on HT trade was not unanimous for all EMU membership countries. The non-unanimous reaction across the member economies suggests that knowledge spillover and diffusion via trade might not be evenly dispersed between the member countries. Moreover, assuming the effects of HT trade on the growth and production structure of the member countries might lead to differences in the production structure and non-synchronous economic shocks, which might further challenge not only the homogeneity of the production structure between member countries, but also the success of the common monetary policy.

We also analyzed the effects of the EMU on total exports. The results of this study lead us to argue that the overall EMU variable is positive and statistically significant, indicating that EMU membership increases total exports. Thus, EMU membership is an important determinant of total exports, which is in line with the results of previous meta-analyses (e.g., Head and Mayer 2014). As a consequence, countries sharing a common currency are likely to trade compared to those with different currencies.

The remainder of this paper is organized as follows. Section 3 discusses the connections between the gravity model and trade. Next, the model and variables are presented, followed by a description of the empirical results. The final section presents the conclusions along with a discussion of the potential implications and limitations of this study.

\footnotetext{
${ }^{2}$ See, for instance, Rose (2000), Rose and van Wincoop (2001), Glick and Rose (2002, 2016), Nitsch (2001), Flam and Nordström (2007) and De Nardis et al. (2008).

${ }^{3}$ For criticisms of the Euro's trade effects and reviews of the most significant empirical studies on the topic, see, for example, Baldwin (2006) and Baldwin and Taglioni (2007).
} 


\section{The Gravity Model and Trade}

The gravity model of international trade is commonly employed for analysis of trade flows between countries ${ }^{4}$. The simplest model explains trade flow between two countries through their Gross Domestic Products (GDPs; size) and the distance between them. Gravity models typically utilize additional explanatory variables that are important from the perspective of the phenomenon in question. The impacts of PTA on trade flows are predominantly analyzed with this equation. However, studies about the effects of the EMU on HT trade and exports are lacking.

Kepaptsoglou et al. (2010) report the results of a meta-analysis of the empirical studies of trade flows and FTA effects during 1999-2009. Many works, such as Rose (2000), Glick and Rose (2002) and Egger (2004), have analyzed whether trade agreements, currency unions or common markets create or divert trade ${ }^{5}$. Gravity models have also been applied to research on trade policy implications and factors affecting trade flows, such as the monetary union (e.g., the EMU) ${ }^{6}$, foreign direct investments ${ }^{7}$, border effects ${ }^{8}$, domino effects ${ }^{9}$, and transportation $\operatorname{costs}^{10}$. The effects on trade of specific products have been studied by certain authors, such as Flam and Nordström (2003), Kangas and Niskanen (2003) and Sarker and Jayasinghe (2007) $)^{11}$.

Earlier studies on the trade effects of the EMU note that its impact on trade between countries sharing a common currency is positive. Baldwin (2006) report these effects to range from 5$10 \%{ }^{12}$ in these studies. Furthermore, Disdier and Head (2008) analyze 1467 distance effects (103 articles) as part of their meta-analysis and report that the negative effect of distance remained high after the mid-20th century. Head and Mayer (2014) augment their dataset using up to 159 papers and over 2500 estimates before conducting a meta-analysis ${ }^{13}$. Their results reveal that GDP elasticities are close to unity, but the GDP elasticity of the destination country is slightly lower (0.84) than the GDP of the originating country. Additionally, the distance elasticity is close to -1 $(-0.93)$. Membership in the EU is associated with a mean coefficient of approximately 0.14 . The

\footnotetext{
${ }^{4}$ Head and Mayer (2014) suggested that this is due to three factors: 1) researchers realised that a large portion of trade data is missing and that gravity models could be used to estimate the missing values, 2) various studies established the relationship between fixed effects in gravity models and varied underlying theories and 3) a convergence gradually occurred, helping scholars connect the dots between the gravity model and the literature concerning heterogeneous firms.

${ }^{5}$ The main results of selected studies on currency union effects are summarised in Appendices 2-4.

${ }^{6}$ See, for instance, Bun and Klaassen (2007). However, Aristotelous (2008) argue that the earlier literature typically studies trade as a whole and pays less attention to individual country effects. Head and Ries (1997) examine the effects on Canadian industries of the Canada-US FTA following its introduction in 1988. Only a few papers, notably Micco et al. (2003) and Aristotelous (2006, 2008), concentrate on studying whether an EMU effect is evenly widespread among EMU members. Arghyroy (2000) analyse the trade effects of the accession of Greece to the EU.

${ }^{7}$ See, for example, De Sousa and Lochard (2011) and Coeurdacier et al. (2009).

${ }^{8}$ See, for instance, Nitsch (2000) and Head and Mayer (2002).

${ }^{9}$ See, e.g., Sapir (2001). The domino effect means that increased integration within FTA members negatively impacts non-members and speeds up their membership applications.

${ }_{10}^{10}$ See, for example, Egger (2008).

${ }^{11}$ Some works focus on the determinants of trade in the used manufacturing/machine sector. Examples include Bond (1983), Mainwaring (1986), Navretti et al. (2000) and Pelletiere and Reinert (2004).

${ }^{12}$ Frankel (2008) argue that the effects of the Euro on trade are typically estimated to be smaller than the trade effects of other currency unions. This is not due to country size, lags (the EMU is younger than other currency unions) or reverse causality. Instead, they attributed these differences to sample size. Thus, the Euro's trade effects expand with a larger numbers of countries and over longer periods.

${ }^{13}$ They extend the distance estimates sample and also analyze estimates other than distance. Their set of new papers augments Disdier and Head's (2008) sample by assessing all papers published in the top five journals, including the Journal of International Economics and the Review of Economics.
} 
effects of a common currency on trade, estimated in terms of the mean over 104 estimates by Head and Mayer (2014), is found to be 0.79 , which indicates a doubling of trade ${ }^{14}$. Glick and Rose (2016) corroborate these results by estimating that membership to the EMU boosts export by approximately $50 \%$.

Also, in contrast with earlier studies as well as the reported trade effects of other currency unions, Santos Silva and Tenreyro (2010) determine that impact of the EMU on trade is close to zero. They explain these results by highlighting that Euro zone countries have historically traded more intensely than other country groups. Camarero, Gớmes and Tamarit (2014) posit that the creation of the EMU is best interpreted as a progression of policy changes which decrease the explicit effects of the Euro on trade. Furthermore, Berger and Nitsch (2008) and Mika and Zymek (2018) report similar results, namely, no significant Euro trade effects.

\section{Modelling and Variables}

In this study, HT sectors are based on the classification used by the OECD STAN BTDIxE Bilateral Trade Database (see Appendix 1). The data comprise the BTDIxE with the exports and imports of goods broken down by industry (trade values are broken down using the 3rd revision of the International Standard Industrial Classification, ISIC Rev. 3) and end-use categories simultaneously (Zhu et al. 2011). The data in the fourth version are maintained and updated by the OECD and are estimates of imports and exports from OECD member as well as a large number of non-OECD countries. The data are expressed in US dollars ${ }^{15}$ and cover the years from 1990 to 2019 for several countries.

Our data cover 27 EU member countries ${ }^{16}$ and the period of 1995-2019 because of lack of data for all the EU countries examined before 1995. The review period also limits the analysis to the period prior to the impact of the Euro crisis. Moreover, limiting the data to after 1992 is logical, since the EU changed its method of collecting trade statistics in 1993 (Baldwin 2006). However, we believe that the available data are sufficient (time is needed for adjustment) to reveal the Euro's effects on trade.

\subsection{Econometric Specifications and Variables}

The gravity equation employed for the econometric analysis to estimate the effects of the EMU on overall bilateral (HT) trade (exports + imports) is as follows:

\footnotetext{
${ }^{14}$ Head and Mayer (2014) argue that this average is larger than the preferred novel estimates (see Baldwin 2006) even though it is lower than the effect reported by Rose (2000), which indicates a tripling of trade due to the common currency. The referenced common currency trade estimates apply to common currency agreements in general and are not specific to the EMU.

${ }^{15}$ Baldwin (2006) note that the common method uses real variables in order not to estimate the trend. However, Baldwin (2006) argue that using US dollars would be reasonable, and deflation of nominal trade and GDP values using the US price index is inappropriate. Furthermore, by including dummy time variables, the mistaken deflation process can be corrected, because all bilateral trade and GDP values are divided by the same price index value.

${ }^{16}$ The data of the following countries are used: Austria, Bulgaria, Belgium, Cyprus, the Czech Republic, Denmark, Estonia, Finland, France, Germany, Greece, Hungary, Ireland, Italy, Latvia, Lithuania, Luxembourg, Malta, the Netherlands, Poland, Portugal, Romania, the Slovak Republic, Slovenia, Spain, Sweden, and the UK. Thus, our data consist of only EU member countries.
} 


$$
\begin{aligned}
\operatorname{In}\left(E_{i j t}\right)= & \beta_{0}+\beta_{1} \operatorname{In}\left(Y_{i t}\right)+\beta_{2} \operatorname{In}\left(Y_{i t}\right)+\beta_{3} \operatorname{In}\left(D_{i j}\right)+\beta_{4} E U_{i j t}+\beta_{5} E M U_{i j t} \\
& +\beta_{6} \operatorname{COMBORD~}_{i j}+\beta_{7} \mathrm{COMLANG}_{i j}+\beta_{8} \mathrm{COLONY}_{i j}+\varepsilon_{i j t}
\end{aligned}
$$

where $\ln$ denotes a natural logarithm, $i$ and $j$ refer to the two countries being analyzed, $t$ refers to the specific year in the period from 1995 to 2019 , and $\varepsilon$ is the error term. $E$ denotes the dependent variable (i.e., the US dollar value of HT trade between countries $i$ and $j$ in period $t$ ).

The sizes of the reporting and partner countries are typically measured using per capita income, income, population or population density. The first independent variables, $\mathrm{Y}_{i t}$ and $\mathrm{Y}_{j t}$, denote the GDPs ${ }^{17}$ of countries $\mathrm{i}$ and $\mathrm{j}$, and they are supposed to capture the effects of economic size on trade (and exports). Table 1 presents the independent variables. Bigger countries (in terms of population, GDP or GDP/capita) create the potential for higher demand for foreign products. Krugman (1980) argued that countries with bigger home markets also enjoy larger exports. Therefore, $Y_{i t}$ and $\mathrm{Y}_{j t}$ are expected to affect trade positively.

Transportation costs, such as tariffs and infrastructure performance, are found to affect trade flows. Reliable data concerning transport costs are usually unavailable, and these costs are thus approximated using the physical distances between trade partners. Let $\mathrm{D}_{\mathrm{ij}}$ indicate the simple distance between the most important cities. Distances are calculated using the latitudes and longitudes of these cities ${ }^{18}$. A negative relationship between distance and trade flow is expected, the assumption being that bigger distances involve extra time and effort and entail higher costs (i.e., transport costs rise, making the trade of goods and services between countries more difficult).

Common explanatory variables in the gravity models include factors indicating barriers to trade (e.g., different language, borders and cultural heritage; lack of past colonial relationships and the same country serving as the reporting and partner country). A dummy variable of countries sharing a border $\left(\mathrm{COMBORD}_{i j}\right)$ is used. This variable takes the value one if the trading partners share a border and zero otherwise. Moreover, a dummy variable for countries sharing a common official language $\left(C O M L A N G_{i j}\right)$ is often used, which takes the value one if trading partners share a common official language and zero otherwise. A dummy variable of countries with past colonial relations $\left(\mathrm{COLONY}_{i j}\right)$ is applied, and it takes the value one if the trading partners ever had colonial relations and zero otherwise.

Participation in custom unions or trade agreements is of great interest, since the seminal study by Rose (2000) reports that countries belonging to the same currency union traded three times more than countries not sharing the same currency. Augmenting gravity models with dummy variables, following the approach of Rose (2000), is now common practice to control the effects of factors such as EU membership. $\mathrm{EU}_{\mathrm{ijt}}$ is a dummy variable describing membership to the EU. It takes the value one when both countries $i$ and $j$ are members of the EU and zero otherwise. In earlier studies, countries belonging to the same trade association reportedly trade more frequently. Thus, we suppose that a common EU membership has a positive effect on HT trade.

\footnotetext{
${ }^{17}$ Source: The World Bank's World Development Indicators. GDP values are converted to international dollars using purchasing power parity rates. Inclusion of exchange rate variables is quite rare in gravity models (see, e.g., Baldwin 2006). Furthermore, Baldwin (2006) argue that there is little difference in the results even if the exchange rate variables (sometimes used in the literature) turn out to be significant, because they arise from a correlation between themselves and the time residual for the relative prices term. We do not use exchange rate variables in our study.

${ }^{18}$ See Mayer and Zignago (2005).
} 
Table 1 Definitions of variables

\begin{tabular}{ll}
\hline Variables & Definitions \\
\hline$E_{\mathrm{ijt}}$ & Dependent variable, HT trade (thousands, US\$) or HT exports $(\times 100$ US\$) \\
GDP reporting & GDP of reporting country \\
GDP partner & GDP of partner country \\
Distance & Distance between the respective pairs of countries \\
EU membership & Membership in the EU \\
& $1=$ both countries $\mathrm{i}$ and $\mathrm{j}$ are members of the EU \\
& $0=$ otherwise \\
EMU overall & Membership in the EMUa \\
& $1=$ both countries $\mathrm{i}$ and $\mathrm{j}$ are members of the EMU \\
& $0=$ otherwise \\
COMBORD & Common border \\
& $1=$ countries share a common border \\
& $0=$ otherwise \\
COMLANG & Share a common official language \\
& $1=$ countries share a common official language \\
& $0=$ otherwise \\
COLONY & Have ever had a colonial relations (linkages) \\
& $1=$ countries have had colonial relations \\
& $0=$ otherwise \\
EMU Austria & Membership in the EMU \\
$1=$ Austria and the other country, j, are members of the EMU \\
$0=$ otherwise \\
\hline
\end{tabular}

The Treaty on the European Union was signed in Maastricht in 1992, and it led to the establishment of the EU. One of the community's goals was the creation of a common market. Increasing economic integration finally led to the establishment of economic and monetary union. The third stage of the EMU was launched on 1 January 1999 in 11 EU countries: Austria, Belgium, Finland, France, Germany, Italy, Ireland, Luxembourg, the Netherlands, Portugal and Spain. Greece joined the EMU on 1 January 2001. Since the birth of the EMU-12 (the first 12 members), Slovenia (in 2007), Cyprus (in 2008), Malta (in 2008), Slovakia (in 2009), Estonia (in 2011) and Latvia (in 2014) have joined the group. However, several EU members have not adopted the Euro as their currency, namely the Czech Republic, Denmark, Hungary, Poland, Sweden and the UK (which have been EU members since 1 May 2004, 1973, 1 May 2004, 1 May 2004, 1995 and 1973, respectively). Thus, adequate data exist with regard to members and non-members in the third stage of the process, which harmonised the economic and monetary policies of the EU members by introducing a single currency (the Euro) and fixing exchange rates.

The dummy EMU variable is designed to capture pairs of countries which use the Euro as their currency. It takes the value zero whenever at least one of the countries is not a member of the EMU.

In most trade studies, the effect of the EMU is positive, meaning that countries sharing a common currency are more likely to trade compared to those with a different currency. Furthermore, Aristotelous (2008) argue that EMU effects on trade might be realized through the following three key elements: 1) lower transaction costs, 2) elimination of exchange rate volatility (uncertainty), and 3 ) enhanced competition. Our purpose is to estimate the impacts of these elements on HT trade. We use the ordinary least squares (OLS) estimation and the Poisson pseudo Maximum Likelihood (PPML) estimator in our analysis of HT exports.

Logarithmic transformations in OLS estimations suffer from one problem; the zero values of bilateral exports are excluded from the analysis. Santos Silva and Tenreyro (2006) argue that this issue could be addressed by a multiplicative form of the gravity equation, and they propose the socalled PPML technique. Furthermore, the traditional approach of taking logarithms to linearize the gravity equation alongside using the OLS estimation may lead to situations where the error term variance depends on regressors creating heteroscedasticity problems. This issue could also be addressed by the PPML technique (Santos Silva and Tenreyro 2006, 2010). Thus, the PPML 
approach can take account of information in zero trade flows. It also considers heteroscedasticity (Santos Silva and Tenreyro 2006; Yotov et al. 2016).

Head and Mayer (2013) argue that heteroscedasticity is a minor concern in logarithmic standard old regressions. In their opinion, the main problem with linear logarithmic regressions is the possibility of inconsistent estimates. Head and Mayer (2013) propose that using the PPML approach instead leads to consistent estimates when the dependent variable takes zero values frequently (see also Santos Silva and Tenreyro 2006, 2010). Thus, "the PPML estimator can be used to estimate theory-consistent general equilibrium effects of trade policies" (Yotov et al. 2016). First, we estimate the EMU membership effects on HT exports.

\section{EMU Effects on HT Exports}

\subsection{OLS Estimation Without Multilateral Resistance Terms}

We analyze the effects of the EMU on bilateral HT exports. We start our analysis with the OLS estimation including standard gravity variables. The multilateral resistances are not taken into account in the standard OLS model. The following model is used.

$$
\begin{aligned}
\operatorname{In}\left(E_{i j t}\right)= & \beta_{0}+\beta_{1} \operatorname{In}\left(Y_{i t}\right)+\beta_{2} \operatorname{In}\left(Y_{i t}\right)+\beta_{3} \operatorname{In}\left(D_{i j}\right)+\beta_{4}\left(E M U_{i j}\right)+\beta_{5}\left(E U_{i j}\right) \\
& +\beta_{6} \mathrm{COMBORD}_{i j}+\beta_{7} \mathrm{COMLANG}_{i j}+\beta_{8} \mathrm{COLONY}_{i j}+\varepsilon_{i j t}
\end{aligned}
$$

where $\ln \left(\mathrm{E}_{i j t}\right)$ denotes the logarithm of bilateral international exports from exporter $i$ to importer $j$ at time t. Table 1 shows the independent variables. The model errors for the trading partners may be correlated. However, the model errors for countries belonging to different trading country pairs are assumed to be uncorrelated. As a consequence, the standard errors are clustered by exporter-importer.

Table 2 (Model 1) explains approximately $73 \%$ of the variance in the dependent variable which can be considered as a strong fit. Overall, our model is in line with the findings of the earlier literature. However, the overall EMU variable is non-significant. The model does not consider multilateral resistances with a set of exporter-time and importer-time fixed effects.

\subsection{Estimations with Multilateral Resistance Terms}

Barriers to trade exist between pairs of countries (termed as bilateral trade resistance). Moreover, one should take note of the barriers to trade that every country faces with all its trading partners (namely multilateral trade resistance). We try to take account of the multilateral resistances in our analysis with a set of exporter-time and importer-time fixed effects. Yotov et al. (2016) argue that exporter-time as well as importer-time fixed effects consider the exporter's and importer's GDPs and other exporter- and importer-specific (observable and unobservable) characteristics influencing bilateral trade (see also Anderson and van Wincoop 2003). Our OLS model is as follows:

$$
\begin{aligned}
\operatorname{In}\left(E_{i j t}\right)= & \beta_{1} \operatorname{In}\left(D_{i j t}\right)+\beta_{2}\left(E M U_{i j t}\right)+\beta_{3}\left(E U_{i j t}\right)+\beta_{4} \text { COMBORD }_{i j t}+\beta_{5} \text { COMLANG }_{i j t} \\
& +\beta_{6} \text { COLONY }_{i j t}+\pi_{i t}+x_{i t}+\varepsilon_{i j t}
\end{aligned}
$$


Table 2 Estimates of the EMU's effects on HT exports ${ }^{\mathrm{a}}$, OLS estimations

Pooled OLS Pooled OLS Pooled OLS Pooled OLS Pooled OLS

(1)

(2)

(3)

(4)

(5)

\begin{tabular}{|c|c|c|c|c|c|}
\hline Ln GDP (reporting) & $1.140 * * *$ & - & - & - & - \\
\hline Ln GDP (Partner) & $0.848 * * *$ & - & - & - & - \\
\hline Ln distance & $-1.223 * * *$ & $-1.257 * * *$ & $-1,575 * * *$ & - & - \\
\hline EU membership & $1.054 * * *$ & $0.696^{* * *}$ & 0,198 & 0.198 & - \\
\hline EMU overall & 0.106 & 0.161 & $-0,140$ & -0.140 & $-0,129$ \\
\hline $\begin{array}{l}\text { Common border (share a } \\
\text { border) }\end{array}$ & -0.089 & -0.014 & $2,972 * * *$ & - & $\mathrm{v}$ \\
\hline Share a common language & 0.394 & -0.049 & $1,326 * * *$ & - & - \\
\hline $\begin{array}{l}\text { Have ever had a colonial } \\
\text { relations }\end{array}$ & $0.854 * * *$ & $0,664 * *$ & $3,544 * * *$ & - & - \\
\hline $\begin{array}{l}\text { Asymmetric Country-pair id } \\
\text { effects }\end{array}$ & no & no & yes & yes & yes \\
\hline Exporter time fixed effects & no & yes & yes & yes & yes \\
\hline Importer time fixed effects & no & yes & yes & yes & yes \\
\hline Observations & 17855 & 18287 & 18287 & 18287 & 18287 \\
\hline $\mathrm{R}^{2}$ & 0.731 & 0.863 & 0,917 & 0,917 & 0,916 \\
\hline Constant & $-33.554 * * *$ & $11.766^{* * * *}$ & $17,589 * * *$ & $4,259 * * *$ & $4,499 * * *$ \\
\hline
\end{tabular}

a Notes: * significant at $10 \%$; ** significant at $5 \%$; *** significant at $1 \%$. Standard errors are clustered by exporter-importer

where $\ln \left(\mathrm{E}_{i j t}\right)$ denotes the logarithm of bilateral exports from exporter $i$ to importer $j$ at time $t$. $\pi_{i t}$ denotes a vector of exporter-time fixed effects, and $\chi_{j t}$ a set of importer-time fixed effects. $\pi_{i t}$ and $\chi_{j t}$ are intended to capture outward multilateral resistances and inward multilateral resistances, respectively. Both fixed effects will absorb the exporter value of output and importer expenditures as well as other observable and unobservable exporter and importer characteristics affecting bilateral trade (see Yotov et al. 2016). Standard errors are clustered by exporter-importer.

For the OLS estimations, we used exporter-time and importer-time fixed effects (Model 2 in Table 2) to control for the unobservable multilateral resistances and characteristics varying over time for the exporters and importers (Anderson and van Wincoop 2003; Yotov et al. 2016). The $R^{2}$ value is even higher (0.863) compared to that of the traditional OLS model (Model 1). The estimates of distance are higher compared to that of the traditional OLS model. The overall EMU effect is higher compared to that in Model 1, but the coefficient is nonsignificant. After including the pair fixed effects, the overall EMU variable becomes negative but remains statistically non-significant (Models 3-5 in Table 2).

We also use the PPML estimator in our analysis (Models 1-6 in Table 3). As stated previously, this estimator can account for the information in zero trade flows as well as heteroscedasticity (Santos Silva and Tenreyro 2006; Yotov et al. 2016). We include pair fixed effects with panel trade data in our gravity and PPML estimations. The pair fixed effects consider the observable and unobservable time-invariant trade costs of bilateral trade. Thus, unobservable trade policy connections with the gravity model error term (or unobservable cross-sectional trade costs) are controlled for with country pair fixed effects. Yotov et al. (2016) consider an example of reverse causality, where a country liberalizes its trade with another country which has been its meaningful trading partner. Thus, the pair fixed effects are supposed to account for the endogeneity of trade policy variables. They also consider the time-invariant bilateral trade costs (Baier and Bergstrand 2007; Yotov et al. 2016). 
Table 3 Estimates of the EMU's effects on HT exports ${ }^{\mathrm{a}}$, PPML estimations

\begin{tabular}{|c|c|c|c|c|c|c|}
\hline $\begin{array}{l}\text { Dependent } \\
\text { variable is HT } \\
\text { exports }\end{array}$ & PPML & PPML & PPML & $\begin{array}{l}\text { PPML bias- } \\
\text { corrected two- } \\
\text { way } \\
\text { (4) }\end{array}$ & $\begin{array}{l}\text { PPML bias- } \\
\text { corrected three- } \\
\text { way } \\
(5)\end{array}$ & $\begin{array}{l}\text { PPML bias- } \\
\text { corrected three- } \\
\text { way } \\
(6)\end{array}$ \\
\hline \multicolumn{7}{|c|}{ Ln GDP (Reporting) } \\
\hline Ln GDP (Partner) & - & - & - & - & - & - \\
\hline Ln distance & $-0.388 * * *$ & - & - & $-0.388 * * *$ & - & - \\
\hline EU membership & $0.434 *$ & -0.133 & - & $0.434 *$ & -0.159 & - \\
\hline EMU overall & 0.158 & -0.042 & $-0,046$ & 0.158 & -0.050 & $-0,055$ \\
\hline $\begin{array}{l}\text { Common border } \\
\text { (share a border) }\end{array}$ & $0.242 * * *$ & - & - & $0.242 * *$ & - & - \\
\hline $\begin{array}{l}\text { Share a common } \\
\text { language }\end{array}$ & -0.018 & - & - & -0.018 & - & - \\
\hline $\begin{array}{l}\text { Have ever had a } \\
\text { colonial } \\
\text { relations }\end{array}$ & $0.337 * *$ & - & - & $0.337 *$ & - & - \\
\hline $\begin{array}{l}\text { Asymmetric } \\
\text { Country-pair id } \\
\text { effects }\end{array}$ & no & yes & yes & no & yes & yes \\
\hline $\begin{array}{l}\text { Exporter time } \\
\text { fixed effects }\end{array}$ & yes & yes & yes & yes & yes & yes \\
\hline $\begin{array}{l}\text { Importer time } \\
\text { fixed effects }\end{array}$ & yes & yes & yes & yes & yes & yes \\
\hline Observations & 18287 & 18287 & 18287 & & & \\
\hline $\mathrm{R}^{2}$ & 0.941 & 0.985 & 0.985 & & & \\
\hline Constant & $21.430 * * *$ & $19.767 * * *$ & $19.640 * * *$ & & & \\
\hline
\end{tabular}

a Notes: * significant at $10 \%$; ** significant at $5 \%$; *** significant at $1 \%$. Standard errors are clustered by exporter-importer

The model in multiplicative form is expressed as follows:

$$
\begin{aligned}
E_{i j t}= & \exp \left(\beta_{1} \operatorname{In}\left(D_{i j t}\right)+\beta_{2}\left(E M U_{i j t}\right)+\beta_{3}\left(E U_{i j t}\right)+\beta_{4} \text { COMBORD }_{i j}+\beta_{5} \text { COMLANG }_{i j}\right. \\
& +\beta_{6} \text { COLONY }_{i j}+\pi_{i t}+x_{i t}+\varepsilon_{i j t}
\end{aligned}
$$

HT export is the dependent variable in the PPML estimations. Negative logarithmic values cannot be used in PPML estimations. The standard errors are clustered by exporter-importer.

After considering the exporter-time and importer-time fixed effects in the two-way gravity model, the overall EMU variable is positive and statistically non-significant (Model 1 in Table 3). Including pair fixed effects (Models 2 and 3) in our gravity estimations with panel trade data results in the sign of the beta coefficient of the overall EMU variable turning negative, and this value remains statistically non-significant.

It has been shown that PPML with two-way (exporter-time and importer-time) fixed effects and three-way (exporter-time, importer-time and country-pair) fixed effects has non-negligible biases (Weidner and Zylkin 2020). We also use bias correction in the PPML estimations (Models 4-6 in Table 3). The results show that the sign of the overall EMU variable in the two-way bias-corrected model (Model 4) is positive, and the value is statistically nonsignificant. The preferred specification (Table 3 in Model 6), namely the three-way biascorrected model, shows that the sign of the overall EMU variable is negative, and its value remains statistically non-significant. 
It is worth stressing that PPML estimations show negative and statistically non-significant overall EMU effects even after considering the bias correction (preferred model, namely Model 6 in Table 3).

Our preferred HT exports results are in line with those of Santos Silva and Tenreyro (2010), who determine that the impact of the EMU on trade is close to zero. They explain the results by highlighting that the Euro zone countries have historically traded more intensely than other country groups. Camarero, Gớmes and Tamarit (2014) posit that the creation of the EMU is best interpreted as a progression of policy changes which decrease the explicit effects of the Euro on trade. Furthermore, Berger and Nitsch (2008) report similar results, namely no significant Euro trade effects.

Márquez-Ramos and Martínez-Zarzoso (2011) note that trade policy barriers are only one element of overall trade costs. They compare the reduction in trade barriers with improving trade facilitation as promoting trade. Moreover, their sectoral data analysis shows that the number of days and number of documents needed for trade as well as information technology achievements serve as factors promoting HT exports among developed countries. However, our data include the old lower-middle income Eastern Bloc countries (Gross National Income (GNI) between US $\$ 1,036$ and US $\$ 4,045$ as of 1 July 2020) and their upper-middle income counterparts (GNI between US\$4,046 and US\$12,535 as of 1 July 2020; see, e.g., World Bank 2020). As a consequence, our dataset consists of high-income countries as well as those for which factors other than trade facilitation might affect exports to a greater degree.

\subsection{EMU Effects on HT Exports in EMU Member Countries: Two-Way Gravity Model Estimations}

Next, we take a closer look at the effects of the EMU on HT exports in the EMU member countries. Tables 4 and 5 reveal how HT exports among the countries belonging to the EMU have changed since joining the monetary union. To sum up, these HT exports changed unevenly between 1999 and 2019, revealing how countries have gained from EMU membership.

EMU dummy variables are used. They take the value one whenever the reporting country shares EMU membership with the partner country. HT exports are the dependent variable for the PPML models. Each country is estimated separately. The original standard errors and biascorrected standard errors of two-way gravity models are shown in Tables 6, 7, and 8 . The beta coefficients differ across models, but the bias correction changes the standard errors of the coefficients. The standard errors are clustered by exporter-importer.

The results of the PPML models (Tables 6, 7, 8) show that after considering exporter-time and importer-time fixed effects, the effect of EMU membership on HT exports becomes negative and statistically significant after bias correction on standard errors for Slovenia and Slovakia. By contrast, HT exports increase for Ireland and Italy. However, the two-way models do not consider the potential endogeneity of the EMUs.

\subsection{EMU Effects on HT Exports in EMU Member Countries: Three-Way Gravity Model Estimations}

As stated previously, the two-way gravity models do not take account of potential endogeneity. Including the pair fixed effects into the models accounts for the endogeneity of the trade policy variables. Consequently, the variables of the standard gravity model that do not vary over time, such as distance, are excluded from the models. Again, each country is estimated separately, and the standard errors are clustered by exporter-importer pairs. 
Table 4 HT exports change with non-EMU countries in 1995-1999 and with non-EMU and EMU countries between year of EMU membership (typically 1.1.1999) and 2019,\%

\begin{tabular}{|c|c|c|c|}
\hline $\begin{array}{l}\text { Reporting } \\
\text { country }\end{array}$ & $\begin{array}{l}\text { Trade with countries by } \\
\text { EMU membership }\end{array}$ & $\begin{array}{l}\text { HT exports change } \\
\text { before } \\
\text { EMU } \\
\text { membership } \\
\%\end{array}$ & $\begin{array}{l}\text { HT exports change } \\
\text { during the EMU membership }\end{array}$ \\
\hline Austria & non-EMU SUM & -54.9 & 117.4 \\
\hline Austria & non-EMU Mean & -28.4 & 310.6 \\
\hline Austria & EMUSum & & 206.8 \\
\hline Austria & EMUMean & & 70.5 \\
\hline Belgium & non-EMU SUM & -64.9 & 167.8 \\
\hline Belgium & non-EMU Mean & -44.2 & 405.8 \\
\hline Belgium & EMUSum & & 186.8 \\
\hline Belgium & EMUMean & & 59.4 \\
\hline Cyprus & non-EMU SUM & 96.4 & 25.4 \\
\hline Cyprus & non-EMU Mean & 307.9 & 81.2 \\
\hline Cyprus & EMUSum & & 1.6 \\
\hline Cyprus & EMUMean & & -26.6 \\
\hline Estonia & non-EMU SUM & 1445.5 & -76.9 \\
\hline Estonia & non-EMU Mean & 3412.6 & -71.7 \\
\hline Estonia & EMUSum & & 44.6 \\
\hline Estonia & EMUMean & & 28.5 \\
\hline Finland & non-EMU SUM & -49.6 & -72.7 \\
\hline Finland & non-EMU Mean & -20.0 & -48.4 \\
\hline Finland & EMUSum & & -60.0 \\
\hline Finland & EMUMean & & -77.8 \\
\hline France & non-EMU SUM & -72.8 & 20.4 \\
\hline France & non-EMU Mean & -56.8 & 127.5 \\
\hline France & EMUSum & & 86.2 \\
\hline France & EMUMean & & 3.5 \\
\hline Germany & non-EMU SUM & -65.2 & 215.8 \\
\hline Germany & non-EMU Mean & -44.7 & 496.5 \\
\hline Germany & EMUSum & & 171.6 \\
\hline Germany & EMUMean & & 50.9 \\
\hline Greece & non-EMU SUM & -62.9 & 58.4 \\
\hline Greece & non-EMU Mean & -37.5 & 181.6 \\
\hline Greece & EMU SUM & & 1427.1 \\
\hline Greece & EMU Mean & & 833.2 \\
\hline Ireland & non-EMU SUM & -43.1 & -7.8 \\
\hline Ireland & non-EMU Mean & -9.7 & 74.1 \\
\hline Ireland & EMUSUM & & 139.7 \\
\hline Ireland & EMUMean & & 33.2 \\
\hline
\end{tabular}

The results of the PPML models (Table 9) considering exporter-time, importer-time and pair fixed effects show that none of the countries benefit from the monetary union (see also Tables 4 and 5; Appendix Fig 1). Table 9 reveals that for Latvia and the Netherlands our bias corrected estimates are negative and statistically significant. Latvia joined the EMU in 2014, and the Netherlands, in 1999. HT exports from Latvia to other countries grew rapidly from 1995 to 2014. However, after joining the EMU, the growth of HT exports to the EMU countries has been much slower. In particular, the data relating to the Netherland's EMU membership are quite long to reveal the effects of the third stage of the EMU process. For the Netherlands after EMU membership (both countries belong to the EMU), the growth of HT exports to EMU countries has been much lower compared to that to non-EMU countries (Table 5 and Appendix Fig 1). 
Table 5 HT exports change with non-EMU countries, Luxembourg was removed, because there are no observations before Luxembourg's EMU membership in 1995-1999 and with non-EMU and EMU countries between year of EMU membership (typically 1.1.1999) and 2019,\%

\begin{tabular}{|c|c|c|c|}
\hline $\begin{array}{l}\text { Reporting } \\
\text { country }\end{array}$ & Trade with countries by EMU membership & $\begin{array}{l}\text { HT exports change } \\
\text { before } \\
\text { EMU } \\
\text { membership } \\
\text { \% }\end{array}$ & $\begin{array}{l}\text { HT exports change } \\
\text { during the EMU membership }\end{array}$ \\
\hline Italy & non-EMU SUM & -71.7 & 102.6 \\
\hline Italy & non-EMU Mean & -55.1 & 282.7 \\
\hline Italy & EMUSum & & 156.9 \\
\hline Italy & EMUMean & & 42.7 \\
\hline Portugal & non-EMU SUM & -78.3 & 229.5 \\
\hline Portugal & non-EMU Mean & -65.6 & 522.4 \\
\hline Portugal & EMUSum & & 123.8 \\
\hline Portugal & EMUMean & & 24.4 \\
\hline Slovenia & non-EMU SUM & 1.7 & 43.9 \\
\hline Slovenia & non-EMU Mean & 83.0 & 139.8 \\
\hline Slovenia & EMUSum & & 177.4 \\
\hline Slovenia & EMUMean & & 84.9 \\
\hline Spain & non-EMU SUM & -77.7 & 108.9 \\
\hline Spain & non-EMU Mean & -64.6 & 294.6 \\
\hline Spain & EMUSum & & 138.6 \\
\hline Spain & EMUMean & & 32.6 \\
\hline the Netherlands & non-EMU SUM & -77.5 & 205.4 \\
\hline the Netherlands & non-EMU Mean & -64.3 & 477.0 \\
\hline the Netherlands & EMUSum & & 147.7 \\
\hline the Netherlands & EMUMean & & 37.6 \\
\hline Latvia & non-EMU SUM & 673.3 & -70.8 \\
\hline Latvia & non-EMU Mean & 1987.9 & -67.6 \\
\hline Latvia & EMUSum & & 99.6 \\
\hline Latvia & EMUMean & & 88.6 \\
\hline Lithuania & non-EMU SUM & 323.7 & -0.8 \\
\hline Lithuania & non-EMU Mean & 1171.0 & -0.8 \\
\hline Lithuania & EMUSum & & 24.9 \\
\hline Lithuania & EMU Mean & & 24.9 \\
\hline Malta & non-EMU SUM & -77.4 & 24.3 \\
\hline Malta & non-EMU Mean & -56.5 & 65.7 \\
\hline Malta & EMUSum & & 14.0 \\
\hline Malta & EMUSum Mean & & -17.7 \\
\hline Slovak republic & non-EMU SUM & 193.6 & 27.3 \\
\hline Slovak republic & non-EMU Mean & 560.6 & 69.7 \\
\hline Slovak republic & EMUSum & & 17.6 \\
\hline Slovak republic & EMUSum Mean & & -2.0 \\
\hline
\end{tabular}

Glick and Rose (2016) use a large sample of countries and a panel model with countrypair fixed effects to show that the effects of the EMU compared to those of other currency unions differ and that the EMU has boosted bilateral exports by approximately $50 \%$. In contrast to this and other studies that show positive effects of the EMU on trade, we propose that it is difficult to identify a single, overall EMU effect on HT exports between countries. Our findings may be attributable to issues such as trade openness, the different levels of economic development of the studied countries or possibly larger effects of the EMU on other industries. Unfortunately, our data cannot provide a firm-level explanation. However, this study does offer novel evidence on the impacts of the EMU on the HT exports of the members of the monetary union. 
Table 6 Estimates of the EMU's effects, Luxembourg was removed, because there are no observations before Luxembourg's EMU membership on HT exportsa, PPML two-way gravity models (exporter-time FE, importertime FE)

\begin{tabular}{|c|c|c|c|c|c|c|c|}
\hline $\begin{array}{l}\text { Dependent variable } \\
\text { is } \\
\text { HT exports }\end{array}$ & beta & $\begin{array}{l}\text { Original } \\
\mathrm{SE}\end{array}$ & $\begin{array}{l}\text { Bias- } \\
\text { corrected } \\
\text { SE }\end{array}$ & $\begin{array}{l}\text { Dependent variable } \\
\text { is } \\
\text { HT exports }\end{array}$ & beta & $\begin{array}{l}\text { Original } \\
\mathrm{SE}\end{array}$ & $\begin{array}{l}\text { Bias- } \\
\text { corrected } \\
\text { SE }\end{array}$ \\
\hline Ln distance & -0.387 & $0.072 * * *$ & $0.088 * * *$ & Ln distance & -0.386 & $0.072 * * *$ & $0.087 * * *$ \\
\hline $\begin{array}{l}\text { Common border } \\
\text { (share a border) }\end{array}$ & 0.258 & $0.076 * * *$ & $0.097 * * *$ & $\begin{array}{l}\text { Common border } \\
\text { (share a border) }\end{array}$ & 0.259 & $0.077 * * *$ & $0.097 * * *$ \\
\hline $\begin{array}{l}\text { Share a common } \\
\text { language }\end{array}$ & -0.009 & 0.250 & 0.289 & $\begin{array}{l}\text { Share a common } \\
\text { language }\end{array}$ & -0.020 & 0.285 & 0.328 \\
\hline $\begin{array}{l}\text { Have ever had a } \\
\text { colonial } \\
\text { relations }\end{array}$ & 0.294 & $0.145^{* *}$ & 0.182 & $\begin{array}{l}\text { Have ever had a } \\
\text { colonial } \\
\text { relations }\end{array}$ & 0.296 & $0.148 * *$ & 0.185 \\
\hline EU membership & 0.496 & $0.239 * *$ & $0.256^{*}$ & EU membership & 0.496 & $0.239 * *$ & $0.256^{*}$ \\
\hline EMU Austria & 0.046 & 0.285 & 0.340 & EMU Belgium & 0.071 & 0.239 & 0.274 \\
\hline constant & $21,436 * * *$ & & & constant & $21,425 * * *$ & & \\
\hline $\mathrm{R}^{2}$ & 0,941 & & & $R^{2}$ & 0.941 & & \\
\hline Ln distance & -0.386 & $0.072 * * *$ & $0.087 * * *$ & Ln distance & -0.384 & $0.071 * * *$ & $0.087 * * *$ \\
\hline $\begin{array}{l}\text { Common border } \\
\text { (share a border) }\end{array}$ & 0.258 & $0.076 * * *$ & $0.096 * * *$ & $\begin{array}{l}\text { Common border } \\
\quad \text { (share a border) }\end{array}$ & 0.259 & $0.076^{* * *} *$ & $0.097 * * *$ \\
\hline $\begin{array}{l}\text { Share a common } \\
\text { language }\end{array}$ & -0.008 & 0.249 & 0.287 & $\begin{array}{l}\text { Share a common } \\
\text { language }\end{array}$ & -0.007 & 0.249 & 0.287 \\
\hline $\begin{array}{l}\text { Have ever had a } \\
\text { colonial } \\
\text { relations }\end{array}$ & 0.293 & $0.144 * *$ & 0.181 & $\begin{array}{l}\text { Have ever had a } \\
\text { colonial } \\
\text { relations }\end{array}$ & 0.290 & $0.144 * *$ & 0.181 \\
\hline EU membership & 0.497 & $0.239 * *$ & $0.256^{*}$ & EU membership & 0.499 & $0.239 * *$ & $0.256^{*}$ \\
\hline EMU Cyprus & 0.277 & 0.530 & 0.561 & EMU Estonia & -1.547 & $1.582 * *$ & 1.815 \\
\hline constant & $21,428 * * *$ & & & constant & $21,415 * * *$ & & \\
\hline $\mathrm{R}^{2}$ & 0,941 & & & $R^{2}$ & 0.941 & & \\
\hline Ln distance & -0.386 & $0.072 * * *$ & $0.087 * * *$ & Ln distance & -0.386 & $0.072 * * *$ & $0.087 * * *$ \\
\hline $\begin{array}{l}\text { Common border } \\
\text { (share a border) }\end{array}$ & 0.258 & $0.076 * * *$ & $0.096 * * *$ & $\begin{array}{l}\text { Common border } \\
\text { (share a border) }\end{array}$ & 0.258 & $0.076 * * *$ & $0.096 * * *$ \\
\hline $\begin{array}{l}\text { Share a common } \\
\text { language }\end{array}$ & -0.008 & 0.249 & 0.287 & $\begin{array}{l}\text { Share a common } \\
\text { language }\end{array}$ & -0.008 & 0.249 & 0.287 \\
\hline $\begin{array}{l}\text { Have ever had a } \\
\text { colonial } \\
\text { relations }\end{array}$ & 0.292 & $0.144 * *$ & 0.181 & $\begin{array}{l}\text { Have ever had a } \\
\text { colonial } \\
\text { relations }\end{array}$ & 0.292 & $0.144 * *$ & 0.181 \\
\hline EU membership & 0.497 & $0.239 * *$ & $0.256^{*}$ & EU membership & 0.497 & $0.239 * *$ & $0.256^{*}$ \\
\hline EMU Latvia & 0.114 & 0.478 & 0.520 & EMU Lithuania & 0.500 & 0.585 & 0.605 \\
\hline constant & $21,429 * * *$ & & & constant & $21,430 * * *$ & & \\
\hline $\mathrm{R}^{2}$ & 0.941 & & & $R^{2}$ & 0.941 & & \\
\hline
\end{tabular}

a Notes: * significant at $10 \%$; ** significant at 5\%; *** significant at $1 \%$.Each country is estimated separately. Standard errors are clustered by exporter-importer

\subsection{Using EMU Partnerships as the Leading Indicator}

We also move the EMU values (EMU series) one and two observations backwards (leading indicator). Table 10 (Models 5 and 6) show that the EMU did not affect HT exports one year before the real EMU partnership came into being. We also analyze if the EMU affected HT exports 2 years before the real EMU partnership (Table 11). Our bias-corrected three-way gravity modelling results show that the EMU partnership dummy variable is negative and statistically significant, indicating that EMU would have affected HT exports negatively two years before the EMU partnership was realized. Notably, the qualification for full EMU membership required fixing the country's exchange rate as per the ERM type target zone 
Table 7 Estimates of the EMU's effects on HT exports ${ }^{\mathrm{a}}$, PPML two-way gravity models (exporter-time FE, importer-time FE)

\begin{tabular}{|c|c|c|c|c|c|c|c|}
\hline $\begin{array}{l}\text { Dependent } \\
\text { variable is } \\
\text { HT exports }\end{array}$ & beta & $\begin{array}{l}\text { Original } \\
\mathrm{SE}\end{array}$ & $\begin{array}{l}\text { Bias- } \\
\text { corrected } \\
\text { SE }\end{array}$ & $\begin{array}{l}\text { Dependent variable is } \\
\text { VAR00072 HT } \\
\text { exports }\end{array}$ & beta & $\begin{array}{l}\text { original } \\
\mathrm{SE}\end{array}$ & $\begin{array}{l}\text { Bias- } \\
\text { corrected } \\
\text { SE }\end{array}$ \\
\hline Ln distance & -0.383 & $0.072 * * *$ & $0.087 * * *$ & Ln distance & -0.403 & $0.072 * * *$ & $0.087 * * *$ \\
\hline $\begin{array}{l}\text { Common border } \\
\text { (share a } \\
\text { border) }\end{array}$ & 0.258 & $0.076^{* * * *}$ & $0.097 * * *$ & $\begin{array}{l}\text { Common border } \\
\text { (share a border) }\end{array}$ & 0.225 & $0.082 * * *$ & $0.104 * *$ \\
\hline $\begin{array}{l}\text { Share a common } \\
\text { language }\end{array}$ & -0.010 & 0.249 & 0.287 & $\begin{array}{l}\text { Share a common } \\
\text { language }\end{array}$ & 0.005 & 0.251 & 0.289 \\
\hline $\begin{array}{l}\text { Have ever had a } \\
\text { colonial } \\
\text { relations }\end{array}$ & 0.291 & $0.144 * *$ & 0.181 & $\begin{array}{l}\text { Have ever had a } \\
\text { colonial relations }\end{array}$ & 0.297 & $0.144 * *$ & 0.181 \\
\hline EU membership & 0.506 & $0.240 * *$ & $0.257 * *$ & EU membership & 0.474 & $0.240 * *$ & $0.257^{*}$ \\
\hline $\begin{array}{l}\text { EMU Finland } \\
\text { constant }\end{array}$ & $\begin{array}{l}-0.317 \\
21,403 * * *\end{array}$ & 0.236 & 0.275 & $\begin{array}{l}\text { EMU France } \\
\text { constant }\end{array}$ & $\begin{array}{l}0.290 \\
21,549 * * *\end{array}$ & $0.159 * *$ & 0.218 \\
\hline $\mathrm{R}^{2}$ & 0,941 & & & $R^{2}$ & 0,941 & & \\
\hline Ln distance & -0.385 & $0.072 * * *$ & $0.087 * * *$ & Ln distance & -0.386 & $0.072 * * *$ & $0.087 * * *$ \\
\hline $\begin{array}{l}\text { Common border } \\
\text { (share a } \\
\text { border) }\end{array}$ & 0.257 & $0.076 * * *$ & $0.098 * * *$ & $\begin{array}{l}\text { Common border } \\
\text { (share a border) }\end{array}$ & 0.258 & $0.076 * * *$ & $0.096^{* * *}$ \\
\hline $\begin{array}{l}\text { Share a common } \\
\text { language }\end{array}$ & -0.011 & 0.246 & 0.285 & $\begin{array}{l}\text { Share a common } \\
\text { language }\end{array}$ & -0.008 & 0.249 & 0.287 \\
\hline $\begin{array}{l}\text { Have ever had a } \\
\text { colonial } \\
\text { relations }\end{array}$ & 0.299 & $0.143 * *$ & $0.180 *$ & $\begin{array}{l}\text { Have ever had a } \\
\text { colonial relations }\end{array}$ & 0.293 & $0.144 * *$ & 0.181 \\
\hline EU membership & 0.494 & $0.239 * *$ & $0.256^{*}$ & EU membership & 0.498 & $0.239 * *$ & $0.256^{*}$ \\
\hline EMU Germany & 0.042 & $0.104 * *$ & 0.138 & EMU Greece & -0.064 & $0.231 * *$ & 0.258 \\
\hline constant & $21,417 * * *$ & & & constant & $21,428 * * *$ & & \\
\hline $\mathrm{R}^{2}$ & 0,941 & & & $R^{2}$ & 0,941 & & \\
\hline Ln distance & -0.372 & $0.072 * * *$ & $0.088 * * *$ & Ln distance & -0.391 & $0.072 * * *$ & $0.087 * * *$ \\
\hline $\begin{array}{l}\text { Common border } \\
\text { (share a } \\
\text { border) }\end{array}$ & 0.287 & $0.080 * * *$ & $0.099 * * *$ & $\begin{array}{l}\text { Common border } \\
\text { (share a border) }\end{array}$ & 0.254 & $0.077 * * *$ & $0.097 * * *$ \\
\hline $\begin{array}{l}\text { Share a common } \\
\text { language }\end{array}$ & 0.063 & 0.231 & 0.272 & $\begin{array}{l}\text { Share a common } \\
\text { language }\end{array}$ & -0.001 & 0.249 & 0.287 \\
\hline $\begin{array}{l}\text { Have ever had a } \\
\text { colonial } \\
\text { relations }\end{array}$ & 0.386 & $0.153 * * *$ & $0.194 * *$ & $\begin{array}{l}\text { Have ever had a } \\
\text { colonial relations }\end{array}$ & 0.281 & $0.144 * *$ & 0.181 \\
\hline EU membership & 0.472 & $0.238 * *$ & $0.255^{*}$ & EU membership & 0.477 & $0.239 * *$ & $0.256^{*}$ \\
\hline EMU Ireland & 0.788 & $0.382 * * *$ & $0.476^{*}$ & EMU Italy & 0.409 & $0.184 * *$ & $0.202 * *$ \\
\hline constant & $21,306^{* * *}$ & & & constant & $21,471 * * *$ & & \\
\hline $\mathrm{R}^{2}$ & 0.942 & & & $R^{2}$ & 0.941 & & \\
\hline
\end{tabular}

a Notes: * significant at $10 \%$; ** significant at $5 \% ; * * *$ significant at $1 \%$. Each country is estimated separately. Standard errors are clustered by exporter-importer

regime at least two years before the adoption of the Euro. Thus, the country pre-commits to applying for the full membership within a 2-year period. We interpret this result as a verification of our previous findings about the effects of the EMU membership on HT trade.

\subsection{HT Exports Explaining EMU Partnerships (Lagged HT Exports)}

As the final step, we estimate a probit model for the EMU membership. We explain the EMU membership by adding the HT exports and the usual explanatory variables in the gravity 
Table 8 Estimates of the EMU's effects on HT exportsa, PPML two-way gravity models (exporter-time FE, importer-time FE)

\begin{tabular}{|c|c|c|c|c|c|c|c|}
\hline $\begin{array}{l}\text { Dependent variable } \\
\text { is } \\
\text { HT exports }\end{array}$ & beta & $\begin{array}{l}\text { Original } \\
\mathrm{SE}\end{array}$ & $\begin{array}{l}\text { Bias- } \\
\text { corrected } \\
\text { SE }\end{array}$ & $\begin{array}{l}\text { Dependent variable } \\
\text { is } \\
\text { HT exports }\end{array}$ & beta & $\begin{array}{l}\text { original } \\
\mathrm{SE}\end{array}$ & $\begin{array}{l}\text { Bias- } \\
\text { corrected } \\
\text { SE }\end{array}$ \\
\hline Ln distance & -0.406 & $0.071 * * *$ & $0,086 * * *$ & Ln distance & -0.385 & $0.072 * * *$ & $0.087 * * *$ \\
\hline $\begin{array}{l}\text { Common border } \\
\text { (share a border) }\end{array}$ & 0.262 & $0.076 * * *$ & $0,098 * * *$ & $\begin{array}{l}\text { Common border } \\
\text { (share a border) }\end{array}$ & 0.259 & $0.076 * * *$ & $0.096 * * *$ \\
\hline $\begin{array}{l}\text { Share a common } \\
\text { language }\end{array}$ & -0.028 & 0.250 & 0,288 & $\begin{array}{l}\text { Share a common } \\
\text { language }\end{array}$ & -0.007 & 0.249 & 0.287 \\
\hline $\begin{array}{l}\text { Have ever had a } \\
\text { colonial } \\
\text { relations }\end{array}$ & 0.314 & $0.145^{* *}$ & $0,183 *$ & $\begin{array}{l}\text { Have ever had a } \\
\text { colonial } \\
\text { relations }\end{array}$ & 0.291 & $0.144 * *$ & 0.181 \\
\hline EU membership & 0.510 & $0.240^{* *}$ & $0,258 * *$ & EU membership & 0.497 & $0.239 * *$ & $0.256^{*}$ \\
\hline EMU Netherlands & -0.496 & $0.222 * * *$ & 0,306 & EMU Portugal & 0.351 & 0.330 & 0.376 \\
\hline constant & $21,585 * * *$ & & & constant & $21,422 * * *$ & & \\
\hline $\mathrm{R}^{2}$ & 0,942 & & & $R^{2}$ & 0,941 & & \\
\hline Ln distance & -0.386 & $0.072 * * *$ & $0,087 * * *$ & Ln distance & -0.386 & $0.072 * * *$ & $0.087 * * *$ \\
\hline $\begin{array}{l}\text { Common border } \\
\text { (share a border) }\end{array}$ & 0.256 & $0.076 * * *$ & $0,096 * * *$ & $\begin{array}{l}\text { Common border } \\
\text { (share a border) }\end{array}$ & 0.258 & $0.076 * * *$ & $0.096 * * *$ \\
\hline $\begin{array}{l}\text { Share a common } \\
\text { language }\end{array}$ & -0.009 & 0.249 & 0,287 & $\begin{array}{l}\text { Share a common } \\
\text { language }\end{array}$ & -0.006 & 0.249 & 0.287 \\
\hline $\begin{array}{l}\text { Have ever had a } \\
\text { colonial } \\
\text { relations }\end{array}$ & 0.298 & $0.144 * *$ & 0,181 & $\begin{array}{l}\text { Have ever had a } \\
\text { colonial } \\
\text { relations }\end{array}$ & 0.290 & $0.145^{* *}$ & 0.181 \\
\hline EU membership & 0.499 & $0.239 * * *$ & $0,256^{*}$ & EU membership & 0.495 & $0.239 * *$ & $0.256^{*}$ \\
\hline EMU Slovenia & -1.164 & $0.593 * * *$ & $0,633^{*}$ & EMU Spain & 0.121 & 0.208 & 0.256 \\
\hline constant & $21,428 * * *$ & & & constant & $21,426 * * *$ & & \\
\hline $\mathrm{R}^{2}$ & 0,941 & & & $R^{2}$ & 0,941 & & \\
\hline Ln distance & -0.384 & $0.072 * * *$ & $0,087 * * *$ & Ln distance & -0.386 & $0.072 * * *$ & $0.087 * * *$ \\
\hline $\begin{array}{l}\text { Common border } \\
\text { (share a border) }\end{array}$ & 0.249 & $0.076 * * *$ & $0,096 * * *$ & $\begin{array}{l}\text { Common border } \\
\text { (share a border) }\end{array}$ & 0.258 & $0.076 * * *$ & $0.096^{* * * *}$ \\
\hline $\begin{array}{l}\text { Share a common } \\
\text { language }\end{array}$ & -0.004 & 0.249 & 0,287 & $\begin{array}{l}\text { Share a common } \\
\text { language }\end{array}$ & -0.007 & 0.249 & 0.287 \\
\hline $\begin{array}{l}\text { Have ever had a } \\
\text { colonial } \\
\text { relations }\end{array}$ & 0.292 & $0.144 * *$ & 0,181 & $\begin{array}{l}\text { Have ever had a } \\
\text { colonial } \\
\text { relations }\end{array}$ & 0.293 & $0.144 * *$ & 0.181 \\
\hline EU membership & 0.502 & $0.239 * *$ & $0,257 *$ & EU membership & 0.498 & $0.239 * *$ & $0.256^{*}$ \\
\hline EMU Slovakia & -0.638 & $0.320 * * *$ & $0,355^{*}$ & EMU Malta & 0.480 & 0.430 & 0.492 \\
\hline constant & $21,421 * * *$ & & & constant & $21,427 * * *$ & & \\
\hline $\mathrm{R}^{2}$ & 0.941 & & & $R^{2}$ & 0.941 & & \\
\hline
\end{tabular}

a Notes: * significant at $10 \%$; ** significant at $5 \%$; *** significant at $1 \%$. Standard errors are clustered by exporter-importer

Each country is estimated separately. Standard errors are clustered by exporter-importer, observations 18287

model equation. The results in Table 12 lend support to the notion that HT exports explain the EMU membership. In effect, these results propose that endogeneity is a potential problem in the EMU estimations as well, as already pointed out by a number of other studies on the effects of PTA on trade (e.g., Baier and Begstrand (2004), Magee (2003), Egger et al. (2011)). Our result thus verifies that we should use estimation methods that take into account the possible endogeneity of the PTA programs and exchange rate arrangements. The findings support our thinking that the inferences should be based on the effects of the EMU on HT trade via the three-way gravity estimation and PPML models, which consider the potential endogeneity problem. 
Table 9 Estimates of the EMU's effects, Luxembourg was removed, because there are no observations before Luxembourg's EMU membership on HT exportsa, PPML three-way gravity models, (exporter-time FE, importer-time FE, country-pair FE)

\begin{tabular}{|c|c|c|c|c|}
\hline \multirow{2}{*}{$\begin{array}{l}\text { Dependent variable is } \\
\text { HT-exports }\end{array}$} & \multicolumn{2}{|c|}{ Original estimates } & \multicolumn{2}{|c|}{ Bias-corrected estimates } \\
\hline & beta & SE & beta & SE \\
\hline EMU Austria & 0.066 & 0.145 & 0.056 & 0.162 \\
\hline EMU Belgium & -0.115 & 0.209 & -0.140 & 0.298 \\
\hline EMU Cyprus & -0.020 & 0.483 & 0.033 & 0.552 \\
\hline EMU Estonia & $-0.892 *$ & 0.745 & -1.280 & 1.256 \\
\hline EMU Latvia & $-0.594 * * *$ & 0.308 & $-0.720 *$ & 0.380 \\
\hline EMU Lithuania & -0.090 & 0.154 & -0.087 & 0.176 \\
\hline EMU Finland & 0.136 & 0.132 & 0.165 & 0.147 \\
\hline EMU France & -0.028 & 0.107 & -0.018 & 0.141 \\
\hline EMU Germany & 0.045 & 0.072 & 0.068 & 0.089 \\
\hline EMU Greece & $0.551 * * *$ & 0.310 & 0.677 & 0.438 \\
\hline EMU Ireland & $0.369^{*}$ & 0.275 & 0.485 & 0.457 \\
\hline EMU Italy & 0.077 & 0.082 & 0.087 & 0.107 \\
\hline EMU Netherlands & $-0.231 * *$ & 0.126 & $-0.307 *$ & 0.164 \\
\hline EMU Portugal & -0.251 & 0.277 & -0.315 & 0.407 \\
\hline EMU Slovenia & 0.200 & 0.237 & 0.218 & 0.266 \\
\hline EMU Spain & -0.182 & 0.199 & -0.231 & 0.309 \\
\hline EMU Slovakia & -0.071 & 0.265 & -0.076 & 0.299 \\
\hline EMU Malta & -0.460 & 0.382 & -0.547 & 0.477 \\
\hline Asymmetric Country-pair id effects & $\mathrm{x}$ & $\mathrm{x}$ & $\mathrm{x}$ & $\mathrm{x}$ \\
\hline Exporter time fixed effects & $\mathrm{x}$ & $\mathrm{x}$ & $\mathrm{x}$ & $\mathrm{x}$ \\
\hline Importer time fixed effects & $\mathrm{x}$ & $\mathrm{x}$ & $\mathrm{x}$ & $\mathrm{x}$ \\
\hline
\end{tabular}

a Notes: * significant at $10 \%$; ** significant at $5 \%$;*** significant at $1 \%$.

Each country is estimated separately. Standard errors are clustered by exporter-importer

\subsection{EMU Effects on Total Exports}

We also estimate EMU membership effects on total exports (Tables 13, 14, 15) to allow comparability to other studies. In sum, the OLS estimates in Table 13 show that a currency union membership is more likely when countries speak the same language, are geographically close (positive common border coefficient and negative distance coefficient) and share former colonial relations. However, the overall EMU variable is statistically non-significant. Our twoway gravity models (Table 14) that take account of multilateral resistances show that the overall EMU variable is positive but statistically non-significant.

However, after adding country-pair fixed effects to the gravity model, the sign of the overall EMU variable remains positive, and its value is statistically non-significant (Models 1 and 2 in Table 15). It has been shown that the PPML approach with two-way and three-way fixed effects has non-negligible biases (Weidner \& Zylkin 2020). As a consequence, we use the bias-corrected PPML (Zylkin 2020) in Models 4-6 (Table 14) and Models 3 and 4 (Table 15). The results show that the sign of the overall EMU variable in the two-way bias-corrected model (Model 5) is positive, and the value is statistically non-significant.

Our three-way estimates (Models 1 and 2 in Table 15) show that the impact of the EMU on total exports is close to zero (see, e.g., Santos Silva and Tenreyro 2010; Camarero et al. 2014; Berger and Nitsch 2008). However, after bias correction, the preferred specification (Model 4 in Table 15) of the three-way bias-corrected model shows that the sign of the overall EMU variable turns positive, and its value becomes statistically significant. As a consequence, our 


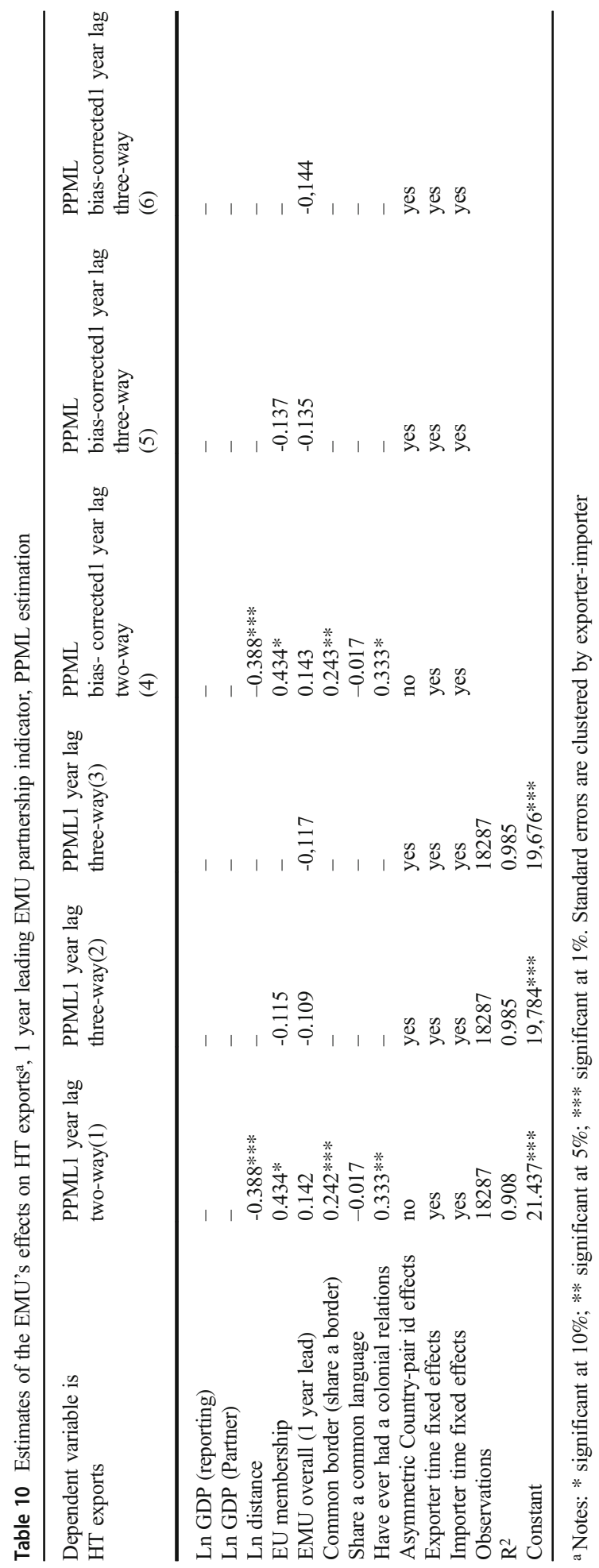




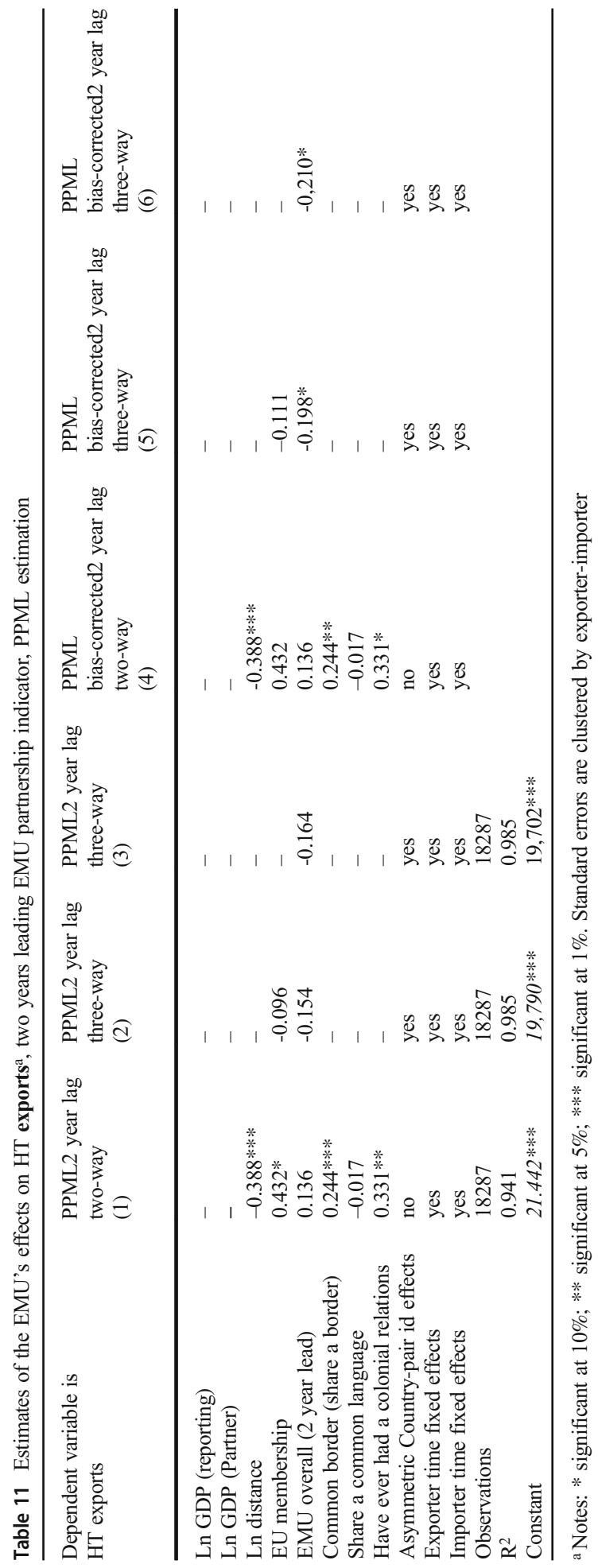


Table 12 Estimates of the HT exports effects on EMU-membershipa, probit regression analysis

\begin{tabular}{|c|c|c|c|c|c|}
\hline $\begin{array}{l}\text { Dependent variable is } \\
\text { EMU partnership }\end{array}$ & (1) & (2) & (3) & (4) & $(5)$ \\
\hline Ln GDP (reporting) & 0.004 & -0.015 & -0.038 & -0.056 & $-0.075 *$ \\
\hline Ln GDP (Partner) & 0.015 & -0.003 & -0.023 & -0.040 & -0.058 \\
\hline Ln distance & $0.341 * * *$ & $0.371 * * *$ & $0.402 * * *$ & $0.428 * * *$ & $0.456^{* * *}$ \\
\hline EU membership & $2.680 * * *$ & $2.655 * * *$ & $2.624 * * *$ & $2.592 * * *$ & $2.555 * * *$ \\
\hline ln HT exports & 0.035 & & & & \\
\hline Ln HT exports 1 year before EMU partnership & & $0.054 * *$ & & & \\
\hline Ln HT exports 2 years before EMU partnership & & & $0.075 * * *$ & & \\
\hline Ln HT exports 3 years before EMU partnership & & & & $0.091 * * *$ & \\
\hline Ln HT exports 4 years before EMU partnership & & & & & $0.109 * * *$ \\
\hline Common border (share a border) & $0.464 *$ & $0.489 *$ & $0.516^{*}$ & $0.543^{*}$ & $0.575^{*}$ \\
\hline Share a common language & $1.087 * * *$ & $1.126 * * *$ & $1.172 * * *$ & $1.230 * * *$ & $1.302 * * *$ \\
\hline Have ever had a colonial relations & -0.790 & -0.840 & -0.897 & -0.959 & -1.032 \\
\hline Observations & 17855 & 17855 & 17855 & 17855 & 17855 \\
\hline $\mathrm{R}^{2}$ & 0.221 & 0.216 & 0.211 & 0.205 & 0,200 \\
\hline Correctly classified (\%) & 77,43 & 76.40 & 75.49 & 74.68 & 73.89 \\
\hline Constant & $-6.469 * * *$ & $-5.841 * * *$ & $-5.129 * * *$ & $-4.537 * *$ & $-3.890 * *$ \\
\hline
\end{tabular}

a Notes: * significant at $10 \%$; ** significant at $5 \%$; *** significant at $1 \%$. Standard errors are clustered by exporter-importer

preferred three-way bias-corrected model for total exports suggests that EMU membership is an important determinant of total exports, which is in line with the meta-analysis results of Head and Mayer (2014).

\section{Conclusions}

Our study contributes fresh insights to the literature on the effects of the PTA and common currency on trade. In particular, we augment the knowledge in the field by examining the

Table 13 Estimates of the EMU's effects on total exports ${ }^{\mathrm{a}}$

Dependent variable is Ln (exports) for models 1-4 Pooled OLS Pooled OLS Pooled OLS Pooled OLS (1)

(2)

(3)

(4)

\begin{tabular}{lllll}
\hline Ln GDP (reporting) & $1.075^{* * *}$ & - & - & - \\
Ln GDP (Partner) & $0.851 * * *$ & - & - & - \\
Ln distance & v1.175*** & $-1.305^{* * *}$ & $-1.579 * * *$ & $0.147^{*}$ \\
EU membership & $0.420^{* * *}$ & $0.320^{* *}$ & $0.147 *$ & 0.003 \\
EMU overall & -0.010 & 0.079 & 0.003 & - \\
Common border (share a border) & $0.371 * *$ & 0.291 & $1.093 * * *$ & - \\
Share a common language & 0.247 & 0.041 & $3.546 * * *$ & - \\
Have ever had a colonial relations & $0.581 * * *$ & $0.624 * * *$ & $-0.681 * * *$ & - \\
Asymmetric Country-pair id effects & no & no & yes & yes \\
Exporter time fixed effects & no & yes & yes & yes \\
Importer time fixed effects & no & yes & yes & yes \\
Observations & 17996 & 18428 & 18428 & 18428 \\
$\mathrm{R}^{2}$ & 0.859 & 0.925 & 0.966 & 0.966 \\
Constant & $-29.493 * * *$ & $16.565 * * *$ & $19.043 * * *$ & $8.610 * * *$ \\
\hline
\end{tabular}

a Notes: * significant at $10 \%$; ** significant at $5 \%$; *** significant at $1 \%$. Standard errors are clustered by exporter-importer 
Table 14 Estimates of the EMU's effects on total exports a, two-way gravity models

\begin{tabular}{|c|c|c|c|c|c|c|}
\hline $\begin{array}{l}\text { Dependent variable is total exports for } \\
\text { models } \\
1-6\end{array}$ & $\begin{array}{l}\text { PPML } \\
\text { (1) }\end{array}$ & $\begin{array}{l}\text { PPML } \\
\text { (2) }\end{array}$ & $\begin{array}{l}\text { PPML } \\
\text { (3) }\end{array}$ & $\begin{array}{l}\text { PPML } \\
\text { (4) } \\
\text { bias- } \\
\text { corrected }\end{array}$ & $\begin{array}{l}\text { PPML } \\
\text { (5) } \\
\text { bias- } \\
\text { corrected }\end{array}$ & $\begin{array}{l}\text { PPML } \\
(6) \\
\text { bias- } \\
\text { corrected }\end{array}$ \\
\hline Ln GDP (reporting) & - & - & - & - & - & - \\
\hline Ln GDP (Partner) & - & - & - & - & - & - \\
\hline Ln distance & $-0.493 * * *$ & - & - & $-0.493 *$ & - & - \\
\hline EU membership & $0.579 * * *$ & 0.109 & - & 0.579 & 0.109 & \\
\hline EMU overall & 0.045 & 0.030 & 0.033 & 0.046 & 0.030 & 0.033 \\
\hline Common border (share a border) & $0.435^{* * * *}$ & - & - & 0.435 & - & - \\
\hline Share a common language & $0.350 * *$ & - & - & 0.350 & - & - \\
\hline Have ever had a colonial relations & $0.395 * * *$ & - & - & 0.395 & - & - \\
\hline Asymmetric Country-pair id effects & no & no & no & no & no & no \\
\hline Exporter time fixed effects & yes & yes & yes & yes & yes & yes \\
\hline Importer time fixed effects & yes & yes & yes & yes & yes & yes \\
\hline Observations & 18428 & 18428 & 18428 & & & \\
\hline $\mathrm{R}^{2}$ & 0.955 & 0.988 & 0.988 & & & \\
\hline Constant & $18.999 * * *$ & $16.623 * * *$ & $16.726^{* * *}$ & & & \\
\hline
\end{tabular}

a Notes: * significant at $10 \%$; ** significant at $5 \%$; *** significant at $1 \%$. Standard errors are clustered by exporter-importer

impacts of a common currency (the Euro) on HT trade. The HT sector has been of special interest for the EU, as stated in the Lisbon Agenda, but none of the previous studies focus on the effects of the common currency on the growth of HT trade within the EU. This topic is important, as HT exports are posited to be a significant driver of knowledge spillovers and economic development in addition to impacting overall trade and growth positively.

Our results of the gravity model estimations for trade propose that economic size, EU membership, distance, common borders, colonial relations and EMU membership are the most important determinants of total export volumes. To estimate the impact of the EMU on export, we extend the analysis using a multilateral resistance term and a three-way gravity (PPML) estimation, and assess

Table 15 Estimates of the EMU's effects on total exports ${ }^{\mathrm{a}}$, three-way gravity models

\begin{tabular}{|c|c|c|c|c|}
\hline Dependent variable is total exports for models $1-4$ & $\begin{array}{l}\text { PPML } \\
\text { (1) }\end{array}$ & $\begin{array}{l}\text { PPML } \\
\text { (2) }\end{array}$ & $\begin{array}{l}\text { PPML } \\
\text { (3) } \\
\text { bias-corrected }\end{array}$ & $\begin{array}{l}\text { PPML } \\
\text { (4) } \\
\text { bias-corrected }\end{array}$ \\
\hline Ln GDP (reporting) & - & - & - & - \\
\hline Ln GDP (Partner) & - & - & - & - \\
\hline Ln distance & - & - & - & - \\
\hline EU membership & 0.109 & - & 0.102 & \\
\hline EMU overall & 0.030 & 0.033 & $0.071 *$ & $0.075 * *$ \\
\hline Common border (share a border) & - & - & - & - \\
\hline Share a common language & - & - & - & - \\
\hline Have ever had a colonial relations & - & - & - & - \\
\hline Asymmetric Country-pair id effects & yes & yes & yes & yes \\
\hline Exporter time fixed effects & yes & yes & yes & yes \\
\hline Importer time fixed effects & yes & yes & yes & yes \\
\hline Observations & 18428 & 18428 & & \\
\hline $\mathrm{R}^{2}$ & 0.997 & 0.997 & & \\
\hline Constant & $16.623 * * *$ & $16.726^{* * *}$ & & \\
\hline
\end{tabular}

a Notes: * significant at $10 \%$; ** significant at $5 \%$; *** significant at $1 \%$. Standard errors are clustered by exporter-importer 
the possible endogeneity of EMU membership. Overall, the effect of the EMU as per the OLS estimation is negative and statistically non-significant. The PPML (preferred) model can consider information on zero trade flows as well as heteroscedasticity. Our three-way bias-corrected estimates show that the sign of the overall EMU variable turns negative while its value remains statistically non-significant. Thus, these results indicate that the impact of the EMU on HT exports is close to zero, which lends support to novel trade studies (see, e.g., Santos Silva and Tenreyro 2010; Camarero et al. 2014; Berger and Nitsch 2008). We also propose that the EMU does not affect all member countries' HT trade unanimously. Moreover, we provide evidence of the significance of the endogeneity of the EMU membership with respect to trade flows. HT trade seems to predict the EMU membership. Our estimates on the non-significant impacts of the EMU on HT trade corroborate our evidence concerning the impacts of the EMU on total exports.

Our study also suffers from some limitations. We examine only the reaction of the aggregated HT exports on the EMU membership. In the future, we plan to examine the impact of the EMU using more disaggregated sectoral- and firm-level trade data.

\section{Appendix 1. Definition of HT sectors.}

The definition of HT sectors is based on the additional aggregates in the OECD BTDIxE industry list (i.e., high R\&D intensity activities). Further information about the OECD and $\mathrm{R} \& \mathrm{D}$ intensity taxonomy can be found at https://doi.org/10.1787/5jlv73sqqp8r-en

HT sector:

- Pharmaceuticals (21)

- Computer, electronics and optical products (26)

- Scientific R\&D (72)

- $\quad$ Air, spacecraft and related machinery (3031)

- Software publishing (5821)

Table 16 High R\&D intensity activities

\begin{tabular}{llll}
\hline $\begin{array}{l}\text { High R\&D } \\
\text { intensity } \\
\text { industries }\end{array}$ & $\begin{array}{l}\text { R\&D as a percent of GVA* } \\
\text { manufacturing }\end{array}$ & $\begin{array}{l}\text { High R\&D intensity } \\
\text { industries }\end{array}$ & $\begin{array}{l}\text { R\&D as a percent of GVA* non- } \\
\text { manufacturing }\end{array}$ \\
\hline $\begin{array}{l}\text { 3031: Air, } \\
\text { spacecraft and } \\
\text { related machinery }\end{array}$ & 31.69 & $72:$ Scientific R\&D & 30.39 \\
$\begin{array}{l}\text { 21: } \\
\begin{array}{l}\text { Pharmaceuticals } \\
\text { 26: Computer, } \\
\text { electronics }\end{array}\end{array}$ & 24.05 & $\begin{array}{l}\text { 5821: Software } \\
\text { publishing }\end{array}$ & 28.94 \\
$\begin{array}{l}\text { and optical } \\
\text { products }\end{array}$ & & & \\
\hline
\end{tabular}

*GVA $=$ Gross value added 


\section{Appendix 2}

Table 17 Studies of currency union effects on trade and their results

\begin{tabular}{|c|c|c|c|}
\hline Author(s) & Data & Country & Results \\
\hline $\begin{array}{l}\text { Rose (2000): One money, } \\
\text { one market: Estimating } \\
\text { the effect of common } \\
\text { currencies on trade }\end{array}$ & $\begin{array}{l}\text { Years } 1970, \\
1975, \\
1980, \\
1985 \text { and } \\
1990 \\
\text { pooled }\end{array}$ & 186 countries & $\begin{array}{l}\text { Countries with a common currency } \\
\text { trade } 3.35 \text { times more with each } \\
\text { other compared to countries with } \\
\text { different currencies }\end{array}$ \\
\hline $\begin{array}{l}\text { Rose and van Wincoop } \\
\text { (2001): National money } \\
\text { as a barrier to interna- } \\
\text { tional trade: The real } \\
\text { case for a currency union }\end{array}$ & $\begin{array}{l}\text { Years } 1970, \\
1975, \\
1980, \\
1985 \text { and } \\
1990 \\
\text { pooled }\end{array}$ & Nearly 200 countries & $\begin{array}{l}\text { A rise in trade among members of the } \\
\text { currency union implies a corresponding } \\
\text { drop in trade with other countries and } \\
\text { with member countries, i.e., the model } \\
\text { implies both trade diversion and trade } \\
\text { creation. } \\
\text { 58\% Euro effect }\end{array}$ \\
\hline $\begin{array}{l}\text { Glick and Rose (2002): } \\
\text { Does a currency union } \\
\text { affect trade? The } \\
\text { time-series evidence }\end{array}$ & $\begin{array}{l}1948- \\
1997 \\
\text { panel da- } \\
\text { ta }\end{array}$ & 217 countries & $\begin{array}{l}\text { Basic gravity model gives the Rose effect as } \\
3.66 \text { times more trade among currency } \\
\text { union pairs; the } \\
\text { fixed effect estimate is } 1.9 \% \text {. }\end{array}$ \\
\hline $\begin{array}{l}\text { Micco et al. (2003): The } \\
\text { Currency Union Effect } \\
\text { on Trade: Early Evi- } \\
\text { dence from EMU }\end{array}$ & $\begin{array}{r}1992- \\
2002\end{array}$ & $\begin{array}{l}22 \text { developed } \\
\text { countries, } 11 \text { are } \\
\text { Euro countries }\end{array}$ & $\begin{array}{l}\text { Several sets of estimates, } 5-20 \% \\
\text { Euro effects on trade between } \\
\text { Euro countries. }\end{array}$ \\
\hline $\begin{array}{l}\text { Flam and Nordström } \\
\text { (2003): Trade volume } \\
\text { effects of the euro: Ag- } \\
\text { gregate and sector esti- } \\
\text { mates }\end{array}$ & $\begin{array}{l}1989- \\
1997 \text { vs. } \\
1998- \\
2002\end{array}$ & $\begin{array}{l}20 \text { industrialized } \\
\text { countries of which } \\
10 \text { are Euro } \\
\text { countries and } 10 \\
\text { non-Euro coun- } \\
\text { tries }\end{array}$ & $\begin{array}{l}\text { The Euro has increased the trade by } 15 \% \\
\text { between Euro countries in } 1998-2002 \\
\text { compared to } 1989-1997 \text {, and the level } \\
\text { of trade with outside countries increased } \\
\text { by } 8 \% \text {. }\end{array}$ \\
\hline $\begin{array}{l}\text { Egger (2004): Estimating } \\
\text { regional trading bloc ef- } \\
\text { fects with panel data }\end{array}$ & $\begin{array}{l}1986- \\
1997 \\
\text { panel da- } \\
\text { ta }\end{array}$ & 47 countries & $\begin{array}{l}\text { Joining a trading bloc does not affect the } \\
\text { short-term } \\
\text { trade volume. Removal of EEA [EEA = } \\
\text { European } \\
\text { Economic Area, which consisted of } \\
\text { member states } \\
\text { of the European Union (EU) and European } \\
\text { Free } \\
\text { Trade Association (EFTA)] explains a re- } \\
\text { duction } \\
\text { of intra-EEA trade volume by } 4 \% \text {. }\end{array}$ \\
\hline
\end{tabular}




\section{Appendix 3}

Table 18 Studies of currency union effects on trade and their results

\begin{tabular}{|c|c|c|c|}
\hline Author(s) & Data & Country & Results \\
\hline $\begin{array}{l}\text { Baldwin and Taglioni (2007): Trade } \\
\text { effects of the euro: a comparison } \\
\text { of estimators }\end{array}$ & $\begin{array}{l}1994 \\
\text {-2003, } \\
\text { panel } \\
\text { data }\end{array}$ & $\begin{array}{l}\text { Six-digit level bilateral product } \\
\text { exports from a single country to } \\
\text { aggregate nineteen destination } \\
\text { countries }\end{array}$ & $\begin{array}{l}3 \text { - } 4 \% \text { Euro effects on trade be- } \\
\text { tween Euro countries and } 3- \\
4 \% \text { effect between Euro and } \\
\text { non-Euro area. }\end{array}$ \\
\hline $\begin{array}{l}\text { Flam and Nordström (2007): } \\
\text { Explaining large Euro effects on } \\
\text { trade: The extensive margin and } \\
\text { vertical specialization }\end{array}$ & $\begin{array}{l}1995 \\
-2005 \\
\text { panel data }\end{array}$ & 10 Euro and 10 non-Euro countries & $\begin{array}{l}26 \% \text { Euro effects on trade between } \\
\text { Euro countries } \\
\text { and } 12-14 \% \text { effect between Euro } \\
\text { and non-Euro area for the years } \\
2002-2005 \text { on average com- } \\
\text { pared to } 1995-1998 \text {. }\end{array}$ \\
\hline $\begin{array}{l}\text { De Nardis et al. (2008): The Euro's } \\
\text { effects on trade in a dynamic set- } \\
\text { ting }\end{array}$ & $\begin{array}{l}1988 \\
-2004, \\
\text { panel } \\
\text { data }\end{array}$ & $\begin{array}{l}23 \text { countries, } 13 \text { EU members and } 10 \\
\text { OECD countries }\end{array}$ & $\begin{array}{l}17 \% \text { Euro effect in the long-term; } \\
\text { in the short-term, the Euro ef- } \\
\text { fect is } 4 \% \text {. }\end{array}$ \\
\hline $\begin{array}{l}\text { Frankel (2008): The estimated effects } \\
\text { of the Euro on trade: Why are } \\
\text { they below historical evidence on } \\
\text { the effects of monetary unions } \\
\text { among smaller countries? }\end{array}$ & $\begin{array}{l}1948- \\
2006 \\
\text { panel } \\
\text { data }\end{array}$ & & $\begin{array}{l}10-25 \% \text { (small sample) and } 300 \% \\
\text { (large sample) Euro effects on } \\
\text { trade between Euro countries. }\end{array}$ \\
\hline $\begin{array}{l}\text { Santos Silva and Tenreyro (2010): } \\
\text { Currency unions in prospect and } \\
\text { retrospect }\end{array}$ & $\begin{array}{l}\text { 1993-2007, } \\
\text { panel data }\end{array}$ & $\begin{array}{l}\text { Comparing trade flows among } \\
\text { Euro-12 with 1) those countries } \\
\text { that were part of the EU in } 1999 \\
\text { but not adopted the euro, 2) EEA } \\
\text { countries and 3) added five addi- } \\
\text { tional OECD countries (Austria, } \\
\text { Canada, Japan, New Zealand and } \\
\text { the USA) }\end{array}$ & $\begin{array}{l}\text { Euro's impact on trade has been } \\
\text { close to zero }\end{array}$ \\
\hline
\end{tabular}

\section{Appendix 4}

Table 19 Studies of currency union effects on trade and their results

\begin{tabular}{|c|c|c|c|}
\hline Author(s) & Data & Country & Results \\
\hline $\begin{array}{l}\text { Berger and Nitsch (2008): Zooming } \\
\text { out: The trade effect of the euro in } \\
\text { historical perspective }\end{array}$ & $\begin{array}{l}\text { 1948-2003, } \\
\text { panel data }\end{array}$ & 22 industrial countries & $\begin{array}{l}\text { Euro's impact on } \\
\text { trade disappears } \\
\text { after controlling } \\
\text { trend }\end{array}$ \\
\hline $\begin{array}{l}\text { Glick and Rose (2016): Currency } \\
\text { unions and trade: A post-EMU } \\
\text { reassessment }\end{array}$ & $\begin{array}{l}\text { 1948-2013, } \\
\text { panel data }\end{array}$ & More than 200 countries & $\begin{array}{l}\text { EMU has boosted } \\
\text { exports by } \\
\text { around } 50 \%\end{array}$ \\
\hline $\begin{array}{l}\text { Mika and Zymek (2018): Friends } \\
\text { without benefits? New EMU } \\
\text { members and the "Euro Effect" } \\
\text { on trade }\end{array}$ & $\begin{array}{l}\text { 1992-2013 } \\
\text { panel data }\end{array}$ & $\begin{array}{l}\text { EU members }+8 \text { developed } \\
\text { economies (Australia, Canada, } \\
\text { Iceland, Japan, New Zealand and } \\
\text { Norway), baseline regressions are } \\
\text { estimated on a sample of } 153 \\
\text { countries }\end{array}$ & $\begin{array}{l}\text { No robust evidence } \\
\text { of a euro effect } \\
\text { on trade }\end{array}$ \\
\hline
\end{tabular}




\section{Appendix 5}
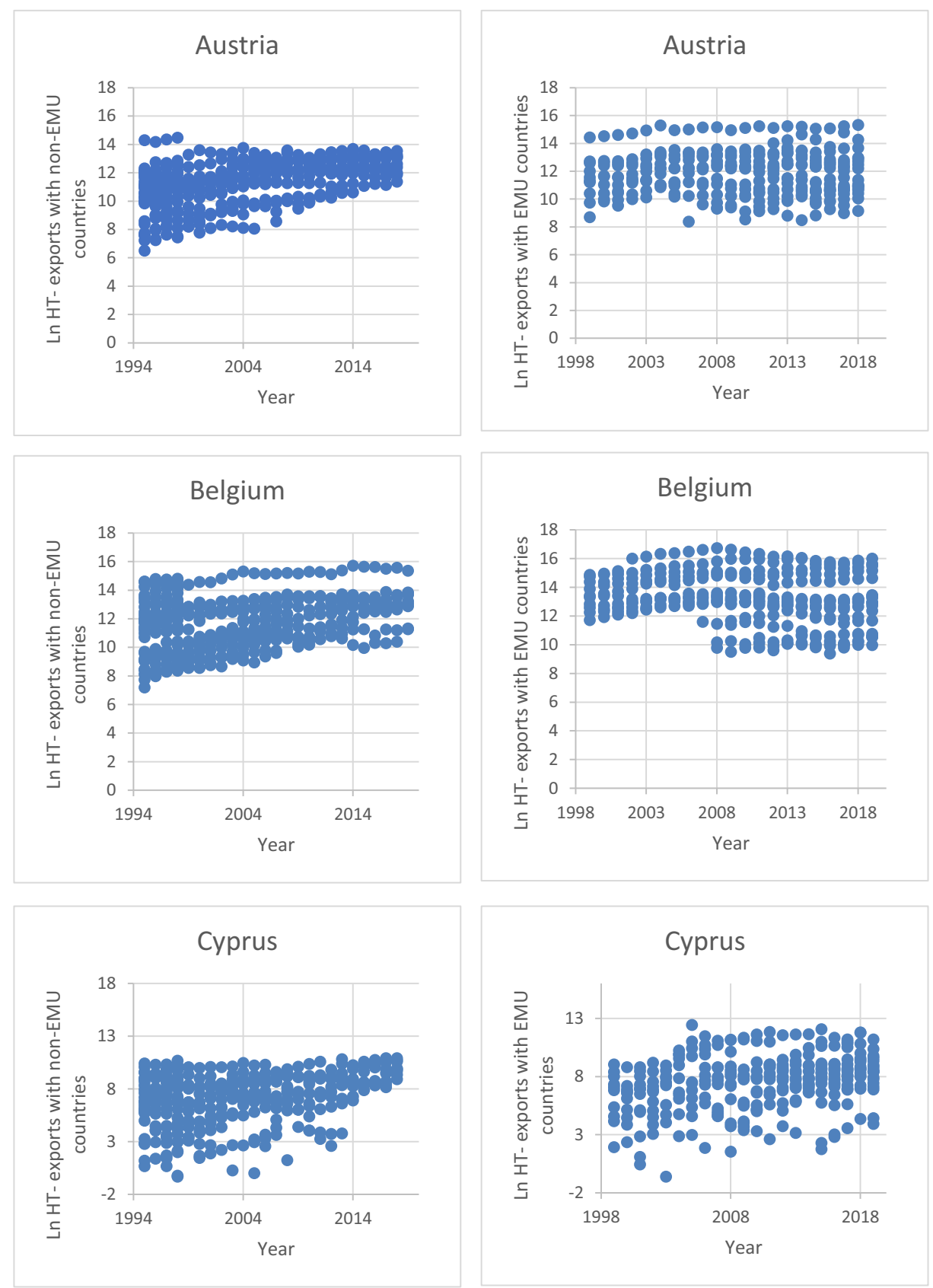

Figure 1. Ln HT-exports $(€)$ with EU countries. Luxembourg was removed, because there are no observations before Luxembourg's EMU membership 

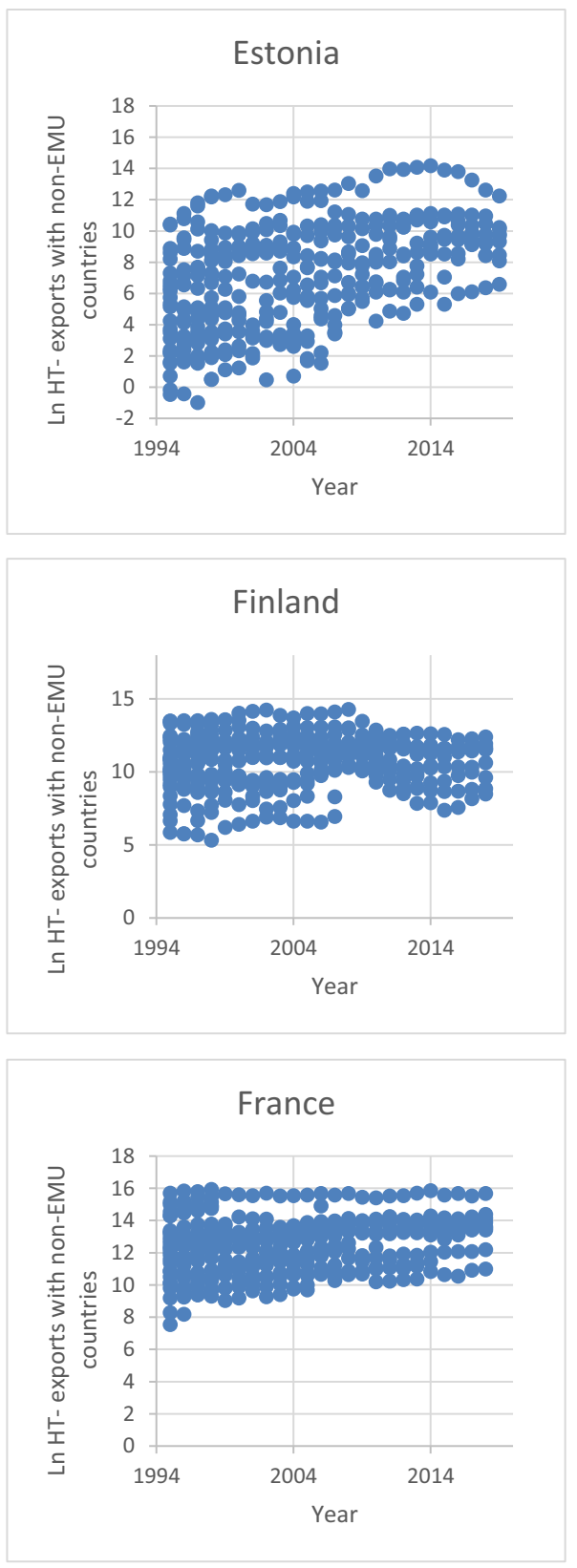

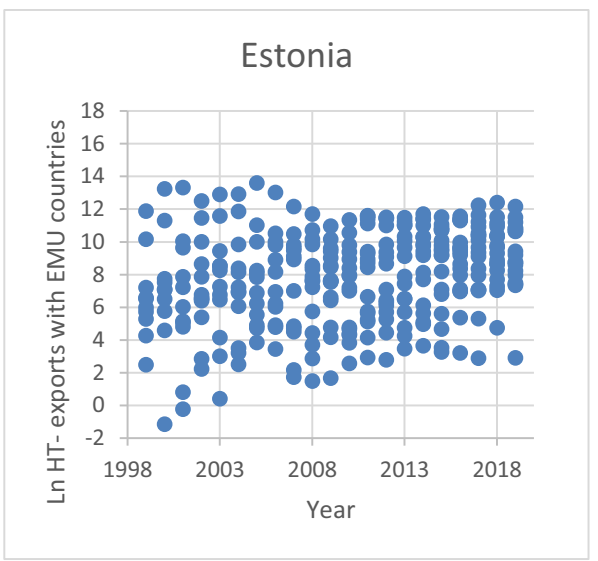

Finland

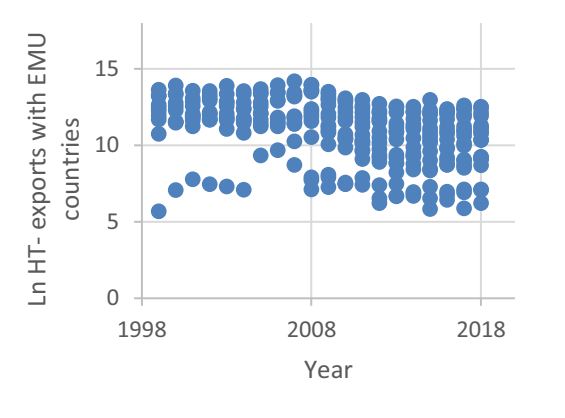

\section{France}

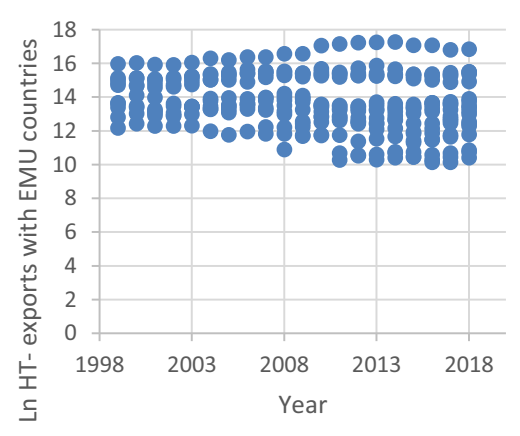

Figure 1. continue 

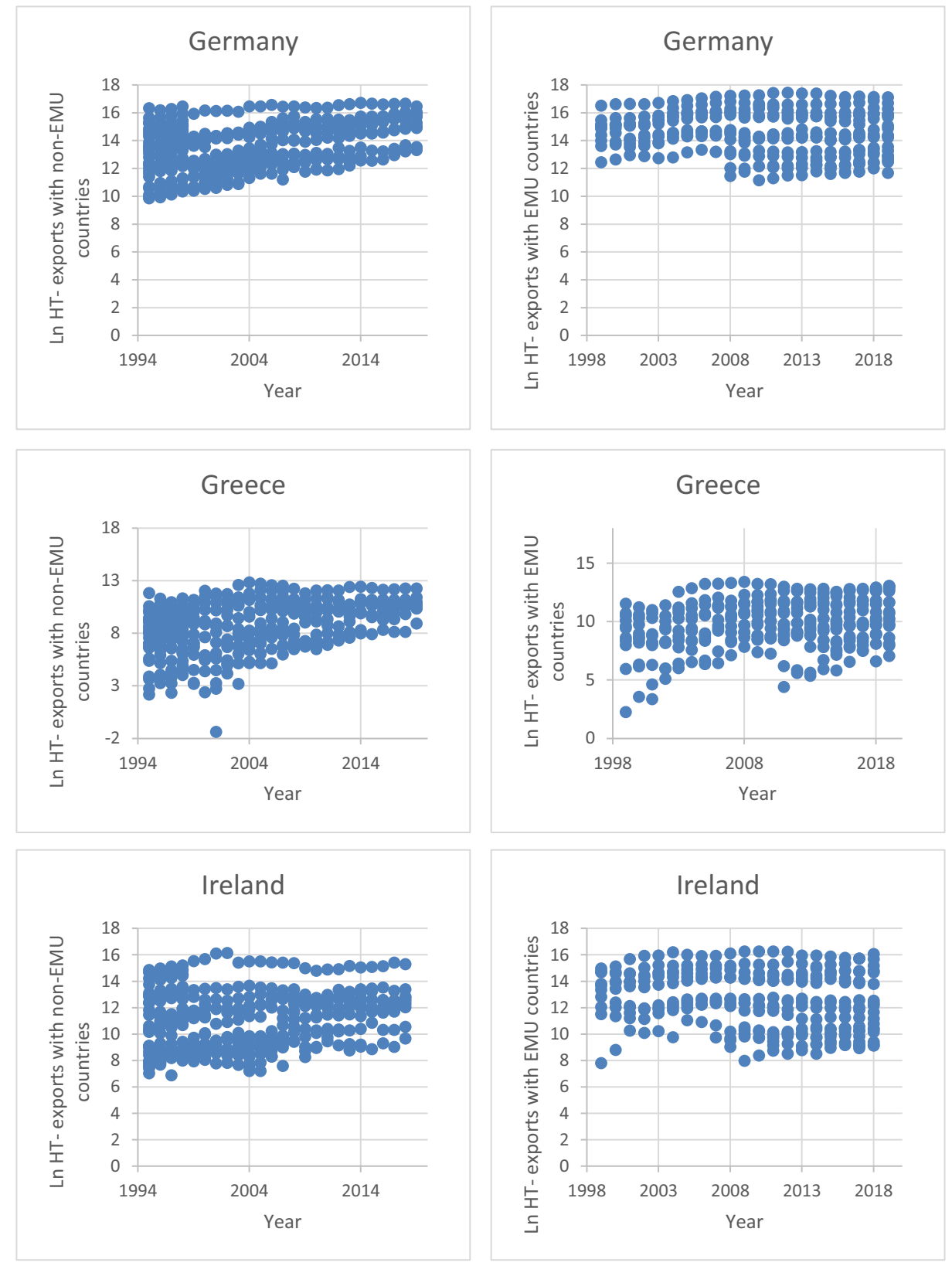

Figure 1. continue 

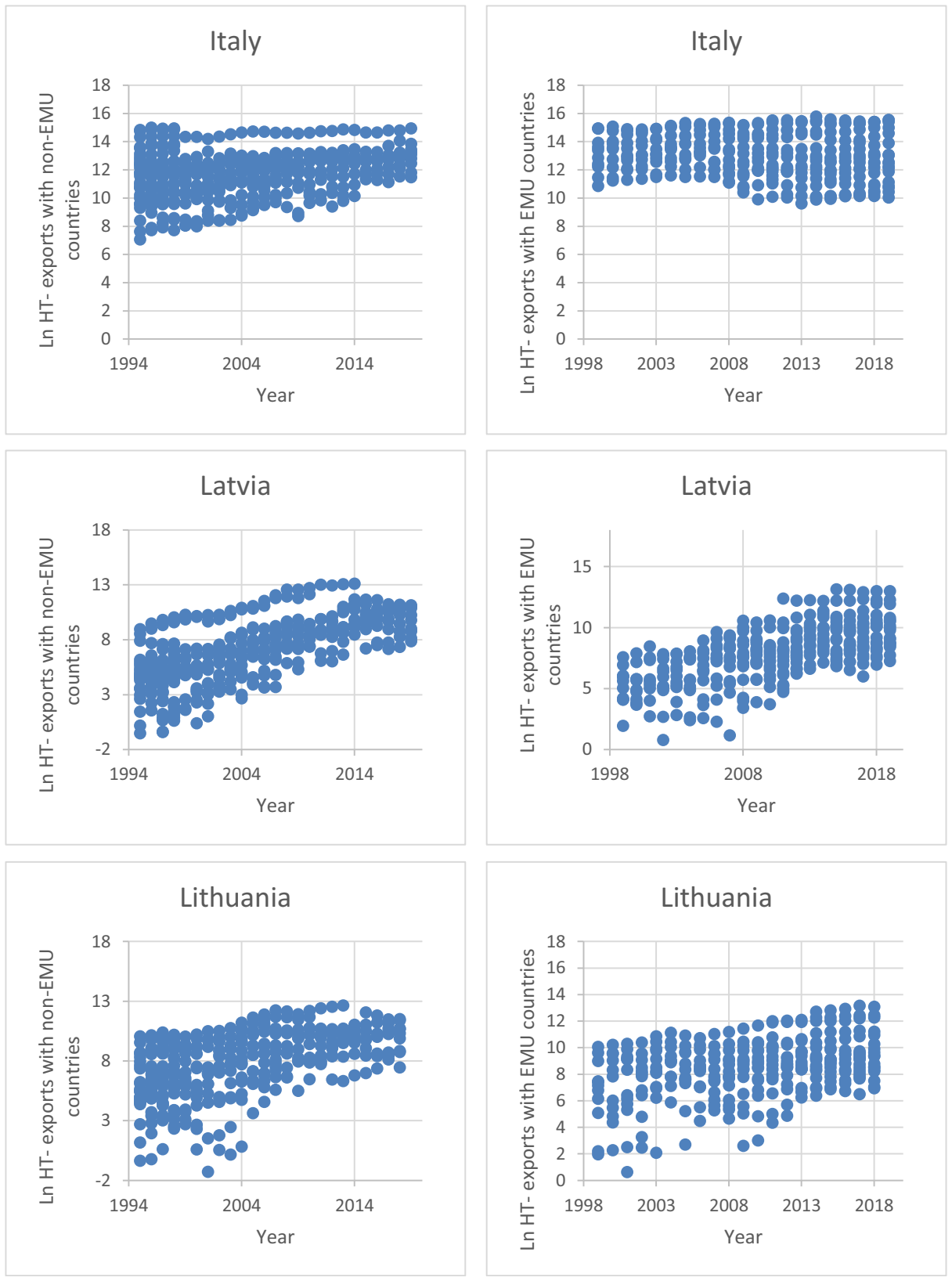

Figure 1. continue 

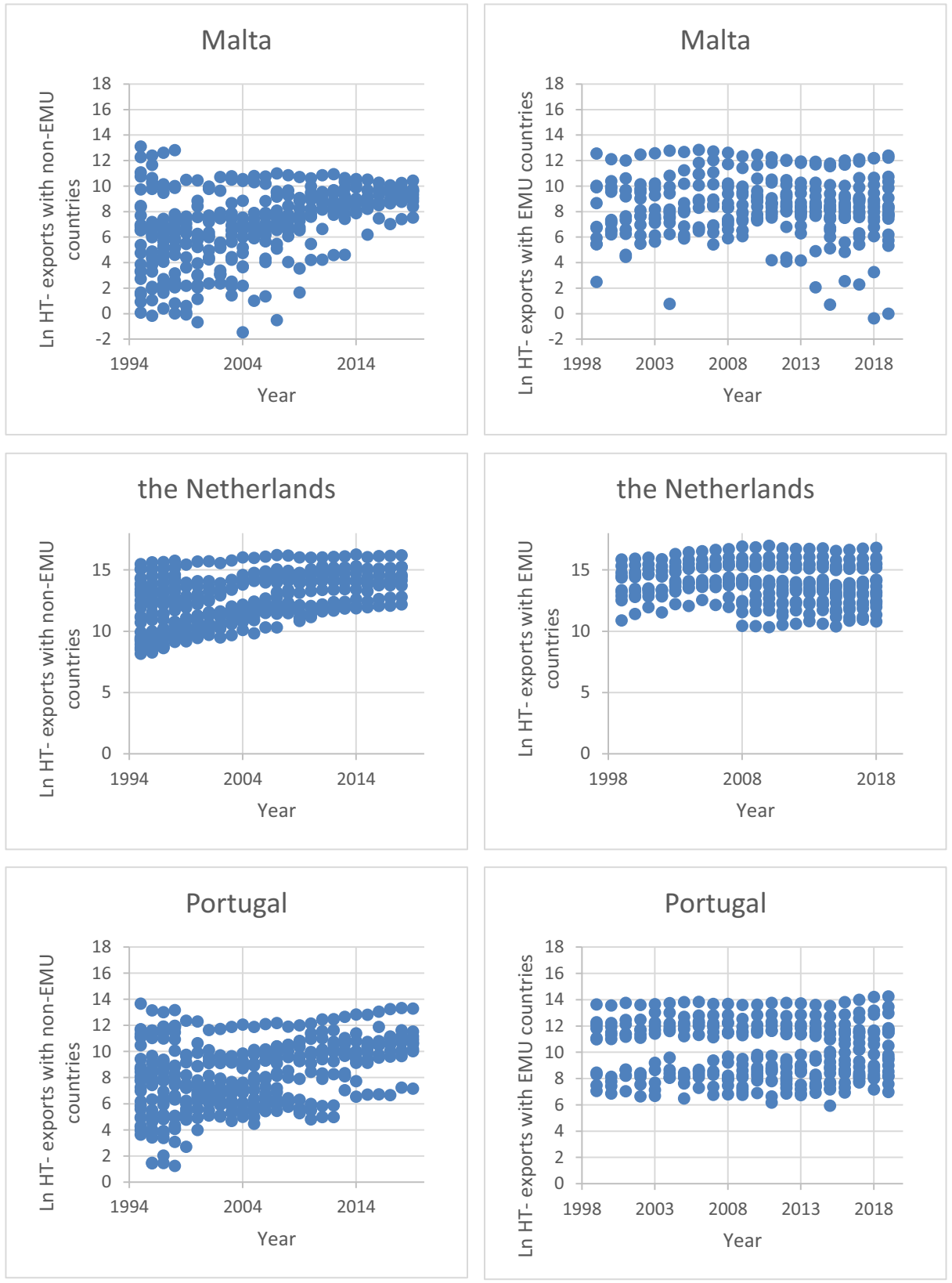

Figure 1. continue 

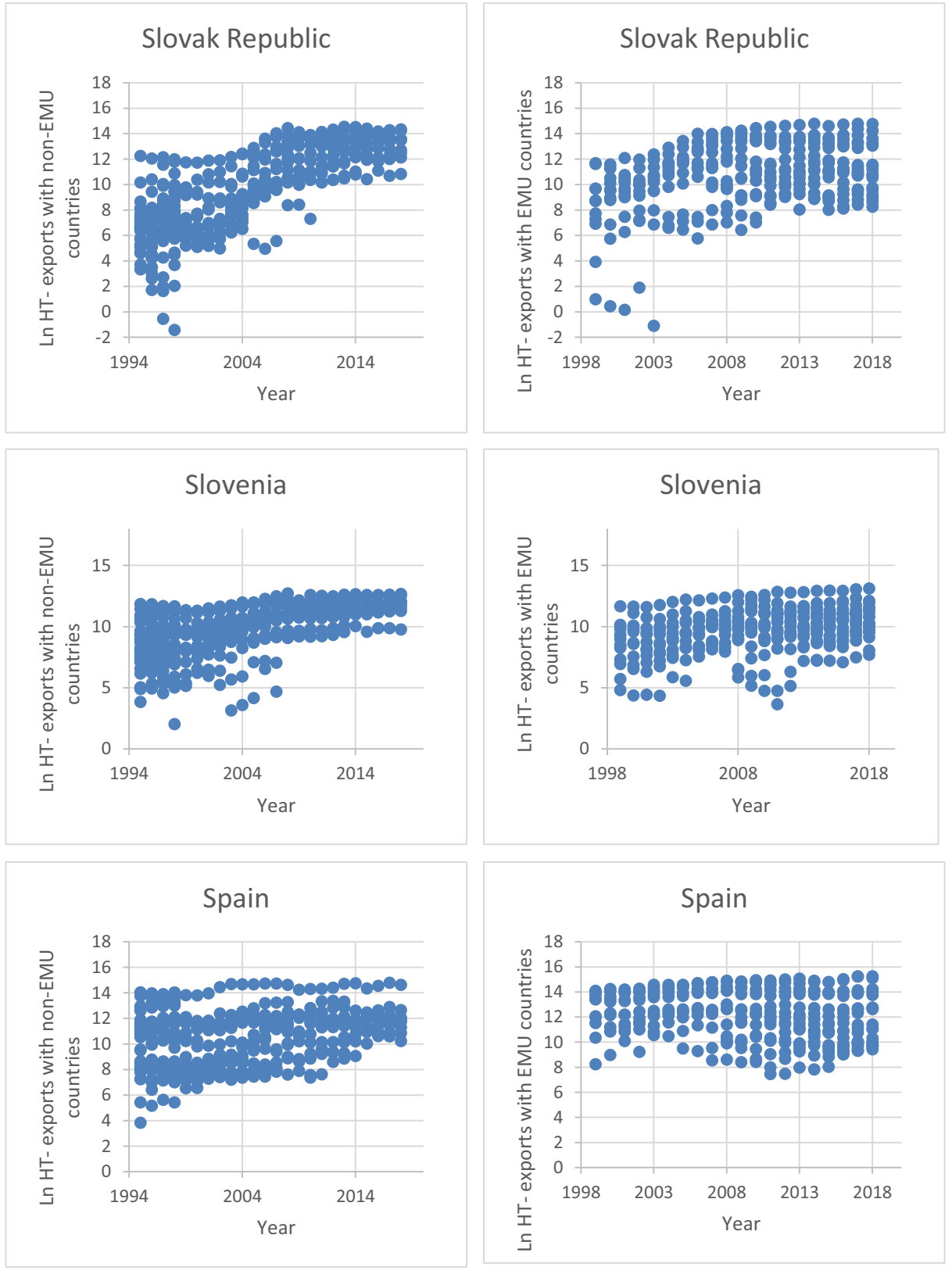

Figure 1. continue 
Acknowledgements Author 2 is grateful to the OP Group Research Foundation and University of Jyvaskyla for their support. The third author is grateful to the OP Group Research Foundation, the Alfred Kordelin Foundation and University of Jyvaskyla for their support.

Funding Open access funding provided by University of Jyväskylä (JYU).

\section{Declarations}

Ethics approval and consent to participate The authors declare that the study did not involve Human Participants and/or Animals. The authors declare that the study did not require informed consents because our study does not meet the human subjects research criteria.

Conflict of interest The authors declare that they have no conflict of interest.

Open Access This article is licensed under a Creative Commons Attribution 4.0 International License, which permits use, sharing, adaptation, distribution and reproduction in any medium or format, as long as you give appropriate credit to the original author(s) and the source, provide a link to the Creative Commons licence, and indicate if changes were made. The images or other third party material in this article are included in the article's Creative Commons licence, unless indicated otherwise in a credit line to the material. If material is not included in the article's Creative Commons licence and your intended use is not permitted by statutory regulation or exceeds the permitted use, you will need to obtain permission directly from the copyright holder. To view a copy of this licence, visit http://creativecommons.org/licenses/by/4.0/.

\section{References}

Anderson JE, van Wincoop E (2003) Gravity with Gravitas: A Solution to the Border Puzzle. Am Econ Rev 93 : $170-192$

Arghyroy MG (2000) EU participation and the external trade of Greece: An appraisal of the evidence. Appl Econ 32:151-159

Aristotelous K (2006) Are there differences across countries regarding the effect currency unions on trade? Evidence from EMU. J Common Mark Stud 44:17-27

Aristotelous K (2008) What is the effect of EMU on Greece's exports to the Eurozone. South-Eastern Europe. J Econ 1:39-51

Audretsch DB, Grimm HM, Schuetze S (2009) Local strategies within a European Policy Framework. Eur Plan Stud 17:463-486

Baier SS, Begstrand JH (2004) Economic determinants of the free trade agreements. J Int Econ 64:24-63

Baier SL, Bergstrand JH (2007) Do free trade agreements actually increase members' international trade? J Int Econ 71:72-95

Baldwin RE (1989) The political economy of trade policy. J Econ Perspect 3(4):119-135

Baldwin R (2006). The Euro's trade effects. European Central Bank. Working paper series, No. 594/ March 2006.

Baldwin R, Taglioni D (2007) Trade Effects of the Euro: A Comparison of Estimators. J Econ Integr 22:780-818

Barro R, Sala-i-Martin X, (1995). Economic Growth. The MIT Press

Berger H, Nitsch V (2008) Zooming out: The trade effect of the euro in historical perspective. J Int Money Financ 27:1244-1260

Bond EW (1983) Trade in used equipment with heterogeneous firms. J Polit Econ 91:688-705

Bun M, Klaassen F (2007) The Euro Effect on Trade is not as Large as Commonly Thought. Oxf Bull Econ Stat 69:473-496

Camarero M, Cómez E, Tamarit C (2014) Is the 'euro effect'on trade small after all? New evidence using gravity equations with panel cointregratio techniques Econ Lett 124:140-142

Carrere C (2006) Revisiting the Effects of Regional Trade Agreements on Trade Lows with Proper Specification of the Gravity Model. Eur Econ Rev 50:223-247

Cecchini P, Catinat M, Jacquemin A (1988) The European challenge 1992: The benefits of a single market. Wildwood House, Aldershot 
Coeurdacier N, de Santis RA, Aviat A (2009) Cross-border mergers and acquisitions and European integration. Econ Policy 57:55-106

De Nardis S, de Santis R, Vicarelli C (2008) The Euro's effects on trade in a dynamic setting. Eur J Comp Econ 5:73-85

De Sousa J, Lochard L (2011) Does the single currency affect foreign direct investment? Scand J Econ 13:553578

Disdier AC, Head K (2008) The Puzzling Persistence of the Distance Effect on Bilateral Trade. Rev Econ Stat 90(1):37-48

Dohse D, Soltwedel R (2006) Recent developments in the research on innovative clusters. Eur Plan Stud 14: 1167-1170

Egger P (2004) Estimating regional trading bloc effects with panel data. Rev World Econ 140:151-166

Egger P (2008) On the role of distance for bilateral trade. World Econ 31:653-662

Egger, P., Straub, K E., Larch M., Winkelman R., (2011). Trade effects of endogenous preferential trade agreements. Am Econ J: Economic Policy. 113-13 (August 2011).

European Commission, (1990). One market, one money. An evaluation of the potential benefits and costs of forming an economic and monetary union. European Economy No 44, October 1990. Commission of the European communities.

Eurostat (2020) Retrieved from: https://ec.europa.eu/eurostat/statistics-explained/index.php/Production_and international_trade_in_high-tech_products\#EU_trade_balance_in_high-tech_products. Accessed $2 \overline{4}$ Aug 2020

Filippini C, Molini V (2003) The Determinants of East Asian Trade Flows: A Gravity Equation Approach. J Asian Econ 14:695-711

Flam H, (2009). The impact of the Euro on international trade and investment: A survey of theoretical and empirical evidence. Swedish inst Eurn Policy Stud, SIEPS 2009:8.

Flam H, Nordström H, (2003). Trade volume effects of the Euro: Aggregate and sector estimates. Institute for international economics studies, Stockholm University. Seminar Paper No. 74.

Flam H, Nordström H, (2007). Explaining large Euro effects on trade: The extensive margin and vertical specialization. Institute for International Economic Studies, Stockholm university, CESifo, mimeo.

Frankel JA (1997) Regional Trading Blocks in the World Economic System. Pearson Institute for International Economics, Washington

Frankel JA, (2008). The estimated effects of the Euro on trade: Why are they below historical evidence on effects of monetary unions among smaller countries?. NBER Working Paper 14542. https://wcfia.harvard.edu/files/ wcfia/files/frankel_estimated.pdf. Accessed 31 Aug 2020

Frankel JA, Rose AK (2002) An Estimate of the Effect of Common Currencies on Trade and Income. Q J Econ 117:437-466

Frankel, JA, Wei, S-J. (1993). Trade Blocks and Currency Blocks. NBER Working Papers No. 4335.

Glick R, Rose AK (2002) Does a currency union affect trade? The time-series evidence. Eur Econ Rev 46:11251151

Glick R, Rose AK (2016) Currency unions and trade: A post-EMU reassessment. Eur Econ Rev 87:78-91

Godin B (2004) The obsession for competitiveness and its impact on statistics: the construction of hightechnology indicators. Res Policy 33:1217-1229

Grossman GM, Helpman E (1991) Trade, knowledge spillovers, and growth. Eur Econ Rev 35(2-3):517-526

Hausman WH, Lee HL, Subramanian U (2013) The impact of logistics performance on trade. Prod Oper Manag 22(2):236-252

Head K, Mayer T (2002) Illusory Border Effects: Distance mismeasurement inflates estimates of home bias in Trade. Centre d'Etudes Perspectives et d'Informations Internationales. CEPII Working Paper, Paris, pp 2002-2001

Head K, Mayer T (2013) What separates us? Sources of resistance to globalization. Can J Econ/Revue canadienne d'économique 46(4):1196-1231

Head K, Mayer T (2014) Gravity equations: Workhorse, toolkit, and cookbook. In: Gopinath G, Helpman E, Rogoff K (eds) Handbook of International Economics, vol 4. Elsevier, Amsterdam, pp 131-195

Head K, Ries J, (1997). Market-access effects of trade liberalization: Evidence from the Canada-U.S. free trade agreement, in: Feenstra RC (Eds.), The effects of U.S. trade protection and promotion policies. University of Chicago Press, pp. 323-342.

Kangas K, Niskanen A (2003) Trade in forest products between European Union and the Central and Eastern European access candidates. Forest Policy Econ 5:297-304

Kepaptsoglou K, Karlaftis MG, Tsamboulas D (2010) The gravity model specification for modeling international trade flows and free trade agreement effects: A 10-year review of empirical studies. Open Econ J 3:1-13

Krugman P (1979) A Model of innovation, technology transfer, and the world distribution of income. J Polit Econ 87(2):23-266 
Krugman P (1980) Scale economics, product differentiation and the pattern of trade. Am Econ Rev 70:950-959

Magee CS (2003) Endogenous Preferential Trade Agreements: An Empirical Analysis. Contr Econ Anal Policy 2(1):1-17

Mainwaring L (1986) International trade in new and used machines. Camb J Econ 10:247-263

Márquez-Ramos L Martínez-Zarzoso I, (2011). Trade Policy versus Trade Facilitation: An Application Using'Good Old'OLS. Econ Discuss Pap (2011-38).

Mayer T, Zignago S, (2005). Notes on CEPII's distances measures: The GeoDist database. CEPII centre, WP No 2011-25.

Micco A, Stein E, Ordoñez G (2003) The Currency Union Effect on Trade: Early Evidence from EMU. Econ Policy 37:317-356

Mika A, Zymek R (2018) Frieds without benefits? New EMU members and the "Euro Effect" on trade. J Int Money Financ 83:75-92

Navretti GG, Soloaga I, Takacs W (2000) Vintage technologies and skill constraints: Evidence from U.S. exports of new and used machines. World Bank Econ Rev 14:91-109

Nitsch V (2000) National borders and international trade: Evidence from the European Union. Can J Econ 33: $1091-1105$

Nitsch V (2001) Honey, I shrunk the currency union effect on trade. World Econ 25:457-474

Pelletiere D, Reinert KA (2004) Used automobile protection and trade: Gravity and ordered probit analysis. Empir Econ 29:737-751

Romer PM (1992) Two strategies for economic development: using ideas and producing ideas. World Bank Econ Rev 6(suppl_1):63-91

Rose AK (2000) One money, one market: Estimating the effect of common currencies on trade. Econ Policy 30: $9-45$

Rose AK, van Wincoop E (2001) National money as a barrier to international trade: The real case for currency union. Am Econ Rev 91:386-390

Santos Silva JMC, Tenreyro S (2006) The log of gravity. Rev Econ Stat 88:641-658

Santos Silva JMC, Tenreyro S (2010) Currency unions in propect and restrospect. Ann Rev Econ 2:51-74

Sapir A (2001) Domino effects in Western European regional trade, 1960-1992. Eur J Polit Econ 17:377-388

Sarker R, Jayasinghe S (2007) Regional trade agreements and trade in agri-food products: Evidence for the European Union from gravity modeling using disaggregated data. Agric Econ 37:93-104

Weidner M Zylkin T, (2020). Bias and consistency in three-way gravity models. arXiv preprint arXiv: $1909.01327 \mathrm{v} 3$.

Yotov YV, Piermartini R, Monteiro J-A, Larch M (2016) An advanced guide to trade policy analysis: The structural gravity model. World Trade Organization, Geneva. https://www.wto.org/english/res_e/booksp_e/ advancedwtounctad2016_e.pdf. Accessed 30 July 2020

World Bank (2020) Analytical Classifications. Bank data, The World

Zhu S, Yamano N, Cimper A, 2011. Compilation of bilateral trade database by industry and end-use category. OECD Publishing, OECD Science, Technology and Industry Working Papers 2011/06.

Zylkin T, (2020). PPML FE BIAS: Stata module to provide bias corrections for Poisson Pseudo-Maximum Likelihood (PPML) gravity models with two-way and three-way fixed effects. Statistical Software Components S458790, Boston College Department of Economics, revised 02 Jun 2020.

Publisher's Note Springer Nature remains neutral with regard to jurisdictional claims in published maps and institutional affiliations. 